\title{
Development of a low-cost cellulase production process using Trichoderma reesei for Brazilian biorefineries
}

\author{
Simo Ellilä ${ }^{1,2^{*}} \mathbb{D}$, Lucas Fonseca' ${ }^{1}$, Cristiane Uchima' ${ }^{1}$ Junio Cota ${ }^{1,3}$, Gustavo Henrique Goldmann ${ }^{4}$,
} Markku Saloheimo², Vera Sacon ${ }^{1}$ and Matti Siika-aho²

\begin{abstract}
Background: During the past few years, the first industrial-scale cellulosic ethanol plants have been inaugurated. Although the performance of the commercial cellulase enzymes used in this process has greatly improved over the past decade, cellulases still represent a very significant operational cost. Depending on the region, transport of cellulases from a central production facility to a biorefinery may significantly add to enzyme cost. The aim of the present study was to develop a simple, cost-efficient cellulase production process that could be employed locally at a Brazilian sugarcane biorefinery.

Results: Our work focused on two main topics: growth medium formulation and strain improvement. We evaluated several Brazilian low-cost industrial residues for their potential in cellulase production. Among the solid residues evaluated, soybean hulls were found to display clearly the most desirable characteristics. We engineered a Trichoderma reesei strain to secrete cellulase in the presence of repressing sugars, enabling the use of sugarcane molasses as an additional carbon source. In addition, we added a heterologous $\beta$-glucosidase to improve the performance of the produced enzymes in hydrolysis. Finally, the addition of an invertase gene from Aspegillus niger into our strain allowed it to consume sucrose from sugarcane molasses directly. Preliminary cost analysis showed that the overall process can provide for very low-cost enzyme with good hydrolysis performance on industrially pre-treated sugarcane straw.

Conclusions: In this study, we showed that with relatively few genetic modifications and the right growth medium it is possible to produce considerable amounts of well-performing cellulase at very low cost in Brazil using T. reesei. With further enhancements and optimization, such a system could provide a viable alternative to delivered commercial cellulases.
\end{abstract}

Keywords: On-site, Cellulase, Enzyme, Trichoderma reesei, Sugarcane, Molasses, Soybean hulls, Brazil, Biorefinery, Cellulosic ethanol

\section{Background}

Lignocellulosic biomass represents perhaps the only viable renewable alternative to petroleum as a raw material for the production of fuels and chemicals in the future. Lignocellulosic biomass is available in abundance in side streams of the agricultural and forest industries across the globe. Converting lignocellulosic biomass into fuels

\footnotetext{
*Correspondence: simo.ellila@vtt.fi

2 Present Address: VTT Technical Research Centre of Finland, Tietotie 2, 02044 Espoo, Finland

Full list of author information is available at the end of the article
}

and chemicals along the standard biochemical route entails a physicochemical pre-treatment of the biomass, followed by enzymatic hydrolysis of the polysaccharide components cellulose and hemicellulose into monomeric sugars. These sugars can then be further fermented into ethanol or other desired compounds.

Although commercial cellulases have improved significantly over the past decade, enzymes remain a significant cost factor in the cellulosic ethanol process [1]. Enzymes can present a particular hurdle in some biomass rich countries such as Brazil, where no domestic industrial 
cellulase production exists and transport infrastructure can be limiting. The industrial production of cellulase enzymes is performed by fermenting highly developed strains of filamentous ascomycete fungi, expertise mainly held by a handful of American and European companies [2].

Several authors have previously discussed the possibility of circumventing the costs associated with enzyme transport by producing the enzymes in a distributed manner at their final site of use ("on-site" enzyme production) [3-6]. As the enzyme would not be transported, cost-savings could be achieved by avoiding process steps such as enzyme clarification and stabilization, and using whole fungal fermentation broth in hydrolysis instead [7, 8]. It is often envisioned that crude raw materials, perhaps the lignocellulosic biomass itself, could be used as the raw material for enzyme production $[1,4,6,9-12]$ and thus significantly lower the cost of the enzymes. Detailed techno-economic modeling has indeed suggested that the carbon source used in enzyme production could account for more than $50 \%$ of the total enzyme cost, if it were pure glucose [5]. Based on the same model, the cost of enzyme $(\$ / \mathrm{kg})$ was found to dramatically impact the minimum ethanol selling price (MESP) of the cellulosic ethanol process [13].

The most common organism cited for the production of cellulases is the mesophilic filamentous ascomycete fungus Trichoderma reesei [14]. Industrial strains and processes have been reported to reach enzyme titers in excess of $100 \mathrm{~g} / \mathrm{l}$ [15]. However, the induction of highlevel cellulase production in conventional T. reesei strains is dependent on inducers such as pure cellulose, lactose or sophorose $[9,16]$, costly media components that would likely render the produced enzymes too expensive for a cellulosic ethanol process.

Furthermore, the secretomes of conventional T. reesei strains generally lack sufficient $\beta$-glucosidase [17] and hemicellulase [11] activities for the enzymes to perform well in the hydrolysis of pre-treated biomass. In biomass hydrolysis studies, it has therefore been common to combine $T$. reesei culture supernatants with enzymes from other fungi secreting higher levels of these enzymes, typically Aspergillus spp. [8, 10, 11, 18, 19]. However, for a simplified low-cost on-site cellulase production process it would be highly desirable to produce all required enzymes from a single host and process. Previous work from several authors suggests ways around the aforementioned problems hampering the use of $T$. reesei as an onsite cellulase producer.

Trichoderma reesei could be modified to produce more enzymes and perhaps on lower cost carbon sources. The primary targets for such modifications would be the transcription factors controlling the production of cellulases.
Several transcription factors relevant in this context have been described in T. reesei, such as CRE1, ACE1, ACE2, HAP2/3/5, XYR1, [20] and more recently others [21]. The expression patterns of some of these transcription factors are already altered in hypercellulolytic strains of $T$. reese $i$ [20]. The expression level of the transcription factor $x y r 1$ seems to be most directly correlated with the expression levels of the main (hemi)cellulases produced by $T$. reesei [22]. Indeed, the overexpression of this transcription factor has been found to lead to increased cellulase production in T. reesei Rut-C30 [23, 24]. Additionally, this transcription factor appears to be involved in the repression of enzyme production on glucose, with a particular mutation $(\mathrm{A} 824 \mathrm{~V})$ being able to abolish this repressive function [25]. Similar results were previously seen with a valine to phenylalanine mutation in the same region of the $A$. niger homologue $(x \ln R)$ of this transcription factor [26]. The residue at this position is conserved in the T. reesei transcription factor (V821). Additional gains in enzyme production by Rut-C30 were seen by down-regulating the repressor ace1 using RNA interference [23].

Several studies have also addressed the main drawback of T. reesei secretomes, namely the lack of sufficient $\beta$-glucosidase activity. The lack of $\beta$-glucosidase leads to the accumulation of cellobiose during hydrolysis, which in turn slows down the activity of the other key cellulases such as cellobiohydrolases and endoglucanases. T. reese $i$ strains have been engineered to overexpress native [27, 28 ] and heterologous [29-33] $\beta$-glucosidases in several prior studies.

In the present study, we aimed to develop a simple cellulase production system based on the filamentous fungus $T$. reesei that could be operated at a Brazilian sugarcane biorefinery. We considered various industrial residues available in Brazil and used them to formulate a simple low-cost culture medium. Additionally, we engineered our production strain to secrete enzymes in the presence of repressing sugars and added a heterologous $\beta$-glucosidase from Talaromyces emersonii to improve the performance of the produced enzymes in hydrolysis. A further addition of an invertase gene from $A$. niger into our strain allowed it to consume sucrose from sugarcane molasses directly, removing the necessity to invert the sucrose using acid or other means.

\section{Results}

\section{Selection of soybean hulls as a carbon source for cellulase production}

Modeling has shown that the primary carbon source used for enzyme production could account for over $50 \%$ of the cost of the final enzyme [5]. We therefore initially aimed to identify industrial residues that could be used in the formulation of a low-cost $T$. reesei culture medium. 
Ideally, such a residue should be available in abundance at low cost, display good rheological properties (i.e., low viscosity), be non-toxic and have high nutrient availability to the enzyme-producing fungus, and induce cellulase production. In the most ideal case, the carbon source would be available at the cellulosic ethanol plant. At a Brazilian sugarcane biorefinery, this could mean in-natura or pre-treated sugarcane bagasse or straw, sugarcane juice, or molasses. However, as we tested these raw materials with unsatisfactory results, we broadened our scope to industrial residues in general. The evaluated residues are listed in Additional file 1, along with our observations regarding the aforementioned factors of price, availability, rheology, toxicity, and enzyme production potential.

Soybean hulls emerged as an excellent residue due to a unique combination of properties based on this simple evaluation. Not only is this residue relatively cheap (\$100-120/t) and available in abundance in Brazil, it contributes to medium viscosity far less than fibrous lignocellulosic residues such as bagasse and contains very little lignin. While the $T$. reesei genome encodes a number of lignin degrading enzymes [34], it is generally not considered to significantly degrade lignin [35]. Lignin can also irreversibly bind cellulases [36] and thus leads to enzyme yield losses.

More crucially, our strain was found to secrete great quantities of extracellular protein when cultivated on milled soybean hulls. Figure 1 shows a comparison of cellulase secretion by T. reesei M44 on sugarcane molasses, sugarcane bagasse, soybean hulls, and cellulase inducer

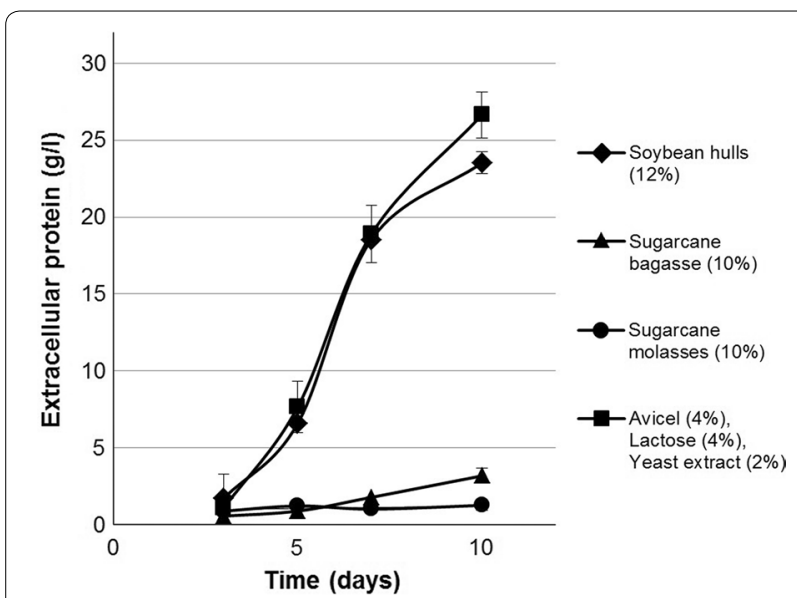

Fig. 1 Extracellular protein production by T. reesei M44 in shake flask culture on select carbon sources. Extracellular protein concentrations measured from culture supernatant samples of T. reesei M44 cultivated on $12 \%$ soybean hulls, $10 \%$ sugarcane bagasse, $10 \%$ sugarcane molasses in mineral medium and a previously optimized combination of $4 \%$ Avicel, $4 \%$ lactose and $2 \%$ yeast extract in sugarcane vinasse medium previously optimized for the strain. This inducer medium comprised Avicel microcrystalline cellulose, lactose, and yeast extract invinasse, the effluent water from sugarcane ethanol distillation. No enzymes were produced on sugarcane molasses, while only very minor amounts $(3.2 \mathrm{~g} / \mathrm{l})$ were produced on sugarcane bagasse. Soybean hulls alone, however, induced the secretion of quantities of enzymes $(23.5 \mathrm{~g} / \mathrm{l})$ approaching those obtained on the optimized inducer medium $(26.6 \mathrm{~g} / \mathrm{l})$. None of the other residues evaluated induced production of more than $10 \mathrm{~g} / \mathrm{l}$ of extracellular enzyme, leading us to focus our attention on soybean hulls.

Soybean hulls were later found to provide nearly all necessary nutrients for the growth and production of enzymes in $T$. reesei cultures. By sequentially removing components of our mineral medium, we found that only the nitrogen source ammonium sulfate was not dispensable (Fig. 2a). However, ammonium sulfate is a relatively inexpensive salt, and liquid ammonia is routinely used to control $\mathrm{pH}$ in $T$. reesei fermentations [16, 20, 37, 38], thus directly providing for a nitrogen source. Additionally, we performed a simple evaluation in shake flasks on soybean hulls milled to different extents demonstrating that a $<2 \mathrm{~mm}$ particle size was sufficient for achieving high enzyme titers (Fig. 2b). Extensive milling could significantly add to the cost of the use of this raw material. We were also able to achieve comparable titers $(19.3 \mathrm{~g} / \mathrm{l})$ in bioreactors in a 96-h cultivation (Additional file 2: Figure S1), corresponding to an overall enzyme productivity of around $0.2 \mathrm{~g} / \mathrm{l} \mathrm{h}$ using only soybean hulls, and ammonium sulfate and ammonia as additional sources of nitrogen.

Although the results obtained with soybean hulls were promising, we estimated that the achieved titers and productivities would not suffice for industrial on-site cellulase production. Depending on the extent of milling, we found that soybean hulls could be used, at most, at concentrations ranging from 100 to $140 \mathrm{~g} / \mathrm{l}$ without compromising medium aeration and cell growth in bioreactors, thus setting an upper limit for maximal obtainable enzyme titers. To achieve yet higher titers and productivities, a soluble carbon source would therefore be required.

\section{Creation of strain VTT-BR-C0019 secreting enzymes in the presence of repressing sugars}

The most obvious choice of soluble carbon source in the context of a Brazilian sugarcane biorefinery was sugarcane molasses. Molasses is a relatively low-cost, highdensity stream from sugar production that in addition to the sugars sucrose, glucose, and fructose contains several other nutrients, and is a common carbon source used for microbial fermentation. The very high sugar 

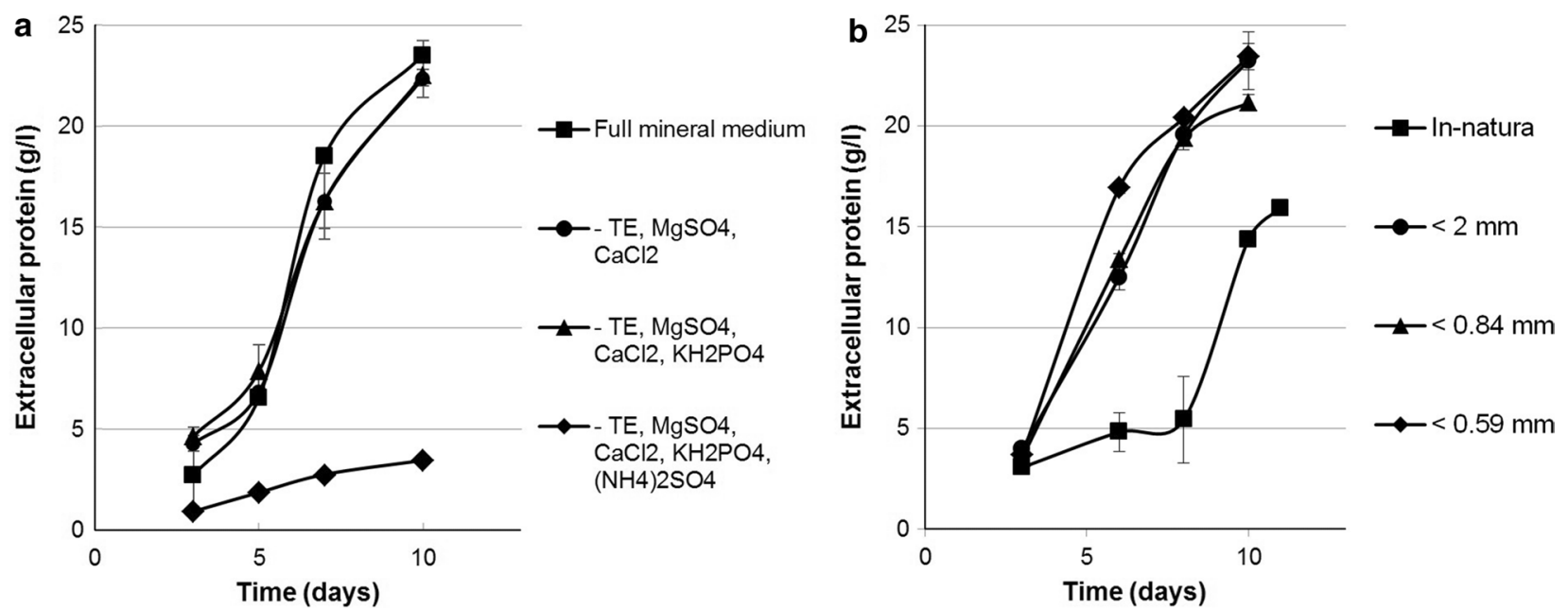

Fig. 2 The effect of salt supplementation and substrate milling on extracellular protein production by T. reesei on soybean hulls. T. reesei (VTT-BRC0019) was cultivated in shake flasks on soybean hull mineral medium under various conditions. a Extracellular protein production on $12 \%$ milled soybean hulls with full mineral medium, with the removal of trace elements, $\mathrm{MgSO}_{4}$ and $\mathrm{CaCl}_{2}$, with the removal of the aforementioned salts and $\mathrm{KH}_{2} \mathrm{PO}_{4}$ and in the absence of all added salts including $\left(\mathrm{NH}_{4}\right)_{2} \mathrm{SO}_{4}$. Only the lack of $\left(\mathrm{NH}_{4}\right)_{2} \mathrm{SO}_{4}$ had a clear negative impact on extracellular protein production. $\mathbf{b}$ Extracellular protein production on 12\% in-natura soybean hulls or with the same amount of soybean hulls milled to pass a 2, 0.84 or $0.59 \mathrm{~mm}$ sieve

concentration of molasses $(\geq 500 \mathrm{~g} / \mathrm{l})$ makes it ideal for use as a fermentation feed. However, the sugars present in molasses (sucrose, glucose, and fructose) are repressing sugars that would inhibit cellulase production in a conventional T. reesei strain. We therefore sought to modify our production strain to be able to use such sugars for cellulase production.

To broaden the range of carbon sources that could be used for cellulase production, we expressed a modified xyr 1 transcription factor under the constitutive pyruvate decarboxylase ( $p d c 1)$ promoter [23] in our production strain. It has been shown that such a modification could lead to increased cellulase production and the expression of endoglucanase when $T$. reese $i$ is cultivated on glucose [23]. We made a single amino acid substitution by replacing a valine residue at position 821 for a phenylalanine (V821F). Previous work suggested that a mutation in this region of the protein could further reduce the repression of enzyme secretion by glucose $[25,26]$.

The strain VTT-BR-C0019 was selected from shake flask screening of transformants. The strain demonstrated higher productivities and overall enzyme titers on an inducing mineral medium containing Avicel and milk whey (Fig. 3b), as well as an enrichment of the xylanolytic activities xylanase and $\beta$-xylosidase (Fig. 3c). Visualization of the secreted proteins by SDS-PAGE also showed clearly stronger bands, which based on their molecular weight likely correspond to the main xylanases (XYN1, XYN2, XYN3) and $\beta$-xylosidase (BXL1) of $T$. reesei (Fig. 3a). This alteration of enzyme profile could be advantageous in the hydrolysis of biomass, as conventional $T$. reesei enzyme preparations are normally considered to contain insufficient amounts of hemicellulolytic enzymes [11]. Most importantly, the strain was found to secrete significant amounts of enzymes also when cultivated on glucose (Fig. 4). Endoglucanase secretion on glucose by a xyr1 overexpressing strain of $T$. reesei has previously been reported [23]. We also saw endoglucanase activity (14.5 $\mathrm{U} / \mathrm{mg}$ ), but additionally we observed significant activity toward xylan $(170 \mathrm{U} / \mathrm{mg})$ and 4-methylumbelliferyl$\beta$-D-lactopyranoside (MUL-9.7 $\mathrm{U} / \mathrm{mg}$ ) in the enzymes produced on this carbon source. Cellobiohydrolase I (CBHI, Cel7A) is the primary T. reesei enzyme with activity toward MUL, but other T. reesei enzymes, particularly endoglucanase I (EGI, Cel7B) also exhibit some activity toward this substrate [37].

The secretome of VTT-BR-C0019 grown in a glucose medium as well as on other carbon sources continued to present the very low levels of $\beta$-glucosidase activity characteristic of T. reesei [39]. In fact, the overexpression of the modified XYR1_V821F transcription factor only seemed to further reduce the specific $\beta$-glucosidase activity of the enzymes produced by the strain (Fig. 3c). We therefore considered the overexpression of a $\beta$-glucosidase the most important second modification to the strain.

\section{Creation of strain VTT-BR-C0020 expressing beta-glucosidase from Talaromyces emersonii}

To increase the $\beta$-glucosidase activity of the enzymes secreted by our strain, we overexpressed the Cel3A $\beta$-glucosidase from the moderately thermophilic fungus 

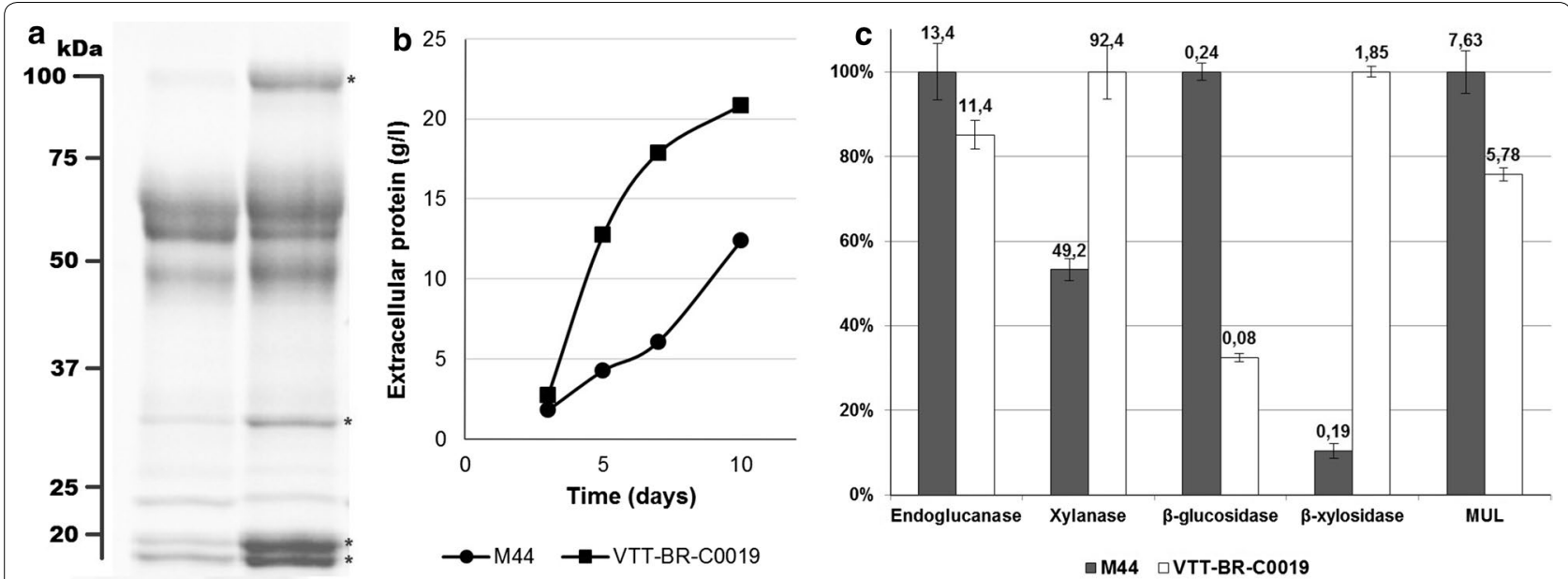

Fig. 3 Production of enzymes by VTT-BR-C0019 in shake flasks on an inducing medium as compared to parental strain M44. T. reesei strains VTT-BRC0019 and M44 were cultivated in shake flasks on an inducing medium comprising 4\% milk whey, 4\% Avicel and 1\% yeast extract. a Culture supernatant samples from the last cultivation day (day 10) visualized on SDS-PAGE. Left lane Parental strain M44, Right lane:VTT-BR-C0019. Asterisks mark the clearly overexpressed proteins, likely corresponding to the main T. reesei xylanolytic enzymes. $\mathbf{b}$ Extracellular protein measured from cultivation samples of the parental strain M44 and VTT-BR-C0019. c Enzyme activity profile of the final cultivation day (day 10) samples. The bars represent the relative specific activities between the parental strain M44 and VTT-BR-C0019, while the numeric labels give the specific activities in units/milligram of protein

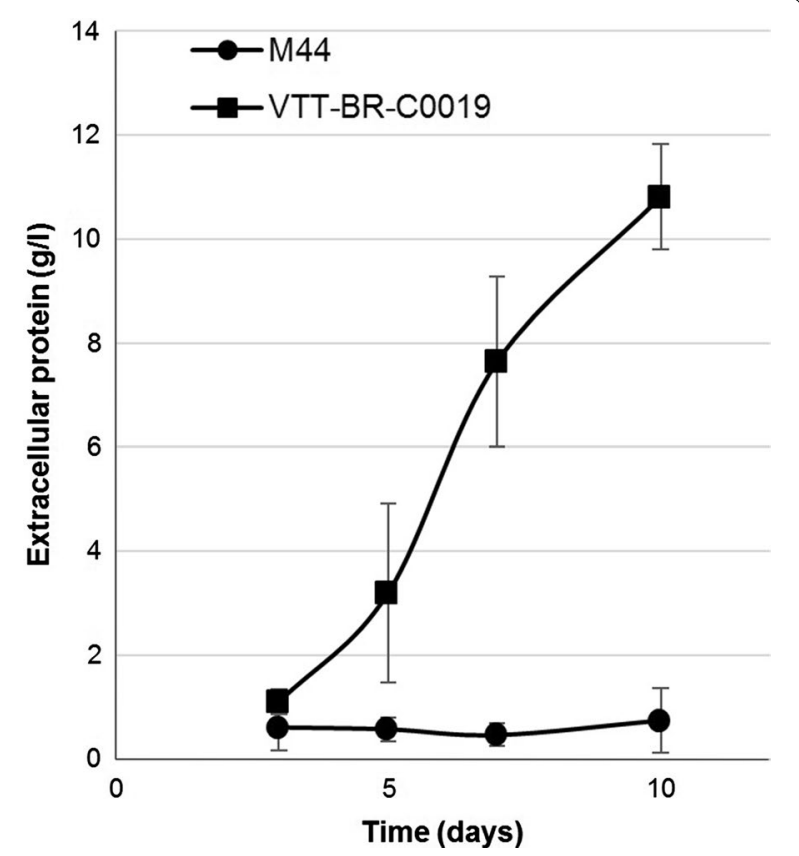

Fig. 4 Production of extracellular protein by VTT-BR-C0019 in shake flasks on a repressing medium as compared to parental strain M44. T. reesei strains VTT-BR-C0019 and M44 were cultivated in shake flasks in mineral medium with $50 \mathrm{~g} / \mathrm{l}$ glucose as carbon source and $10 \mathrm{~g} / \mathrm{l}$ yeast extract as organic nitrogen source

Rasamsonia (Talaromyces) emersonii. This enzyme has previously been expressed in $T$. reese $i$ and characterized [30]. The constitutive expression of XYR1_V821F had led to a significant overexpression of xylanases (Fig. 3a, c), at levels we considered more than adequate for the hydrolysis of most types of pre-treated biomass. We therefore decided to utilize the $x y n 1$ promoter to drive the $\beta$-glucosidase expression. The use of more standard T. reesei cellulase promoters, such as that of cel7a, was avoided primarily for the fear of decreasing native cellulase expression. The bar gene conferring resistance to phosphinothricin (glufosinate) [40] was used as selectable marker. As previously, we selected a single transformant (VTT-BR-C0020) displaying the best characteristics (consistent high level of $\beta$-glucosidase production) in shake flask culture (Fig. 5). This strain was found to produce similar amounts of extracellular protein as the parental strain VTT-BR-C0019 on an inducing medium (Fig. 5b), but additionally up to $146 \mathrm{U} / \mathrm{ml}$ total or $8 \mathrm{U} /$ mg specific $\beta$-glucosidase activity. The heterologous protein was also clearly visible on SDS-PAGE (Fig. 5a). We therefore had a strain secreting enzymes on repressing sugars and secreting higher levels of xylanolytic enzymes, as well as $\beta$-glucosidase, compared to the original strain M44.

\section{Evaluation of the enzymes produced using strain VTT-BR-C0020 on soybean hulls and sugarcane molasses} To evaluate the performance of the new strain VTT-BRC0020, a bioreactor cultivation was performed with the batch medium comprising only soybean hulls and ammonium sulfate and with a feed comprising only sugarcane 

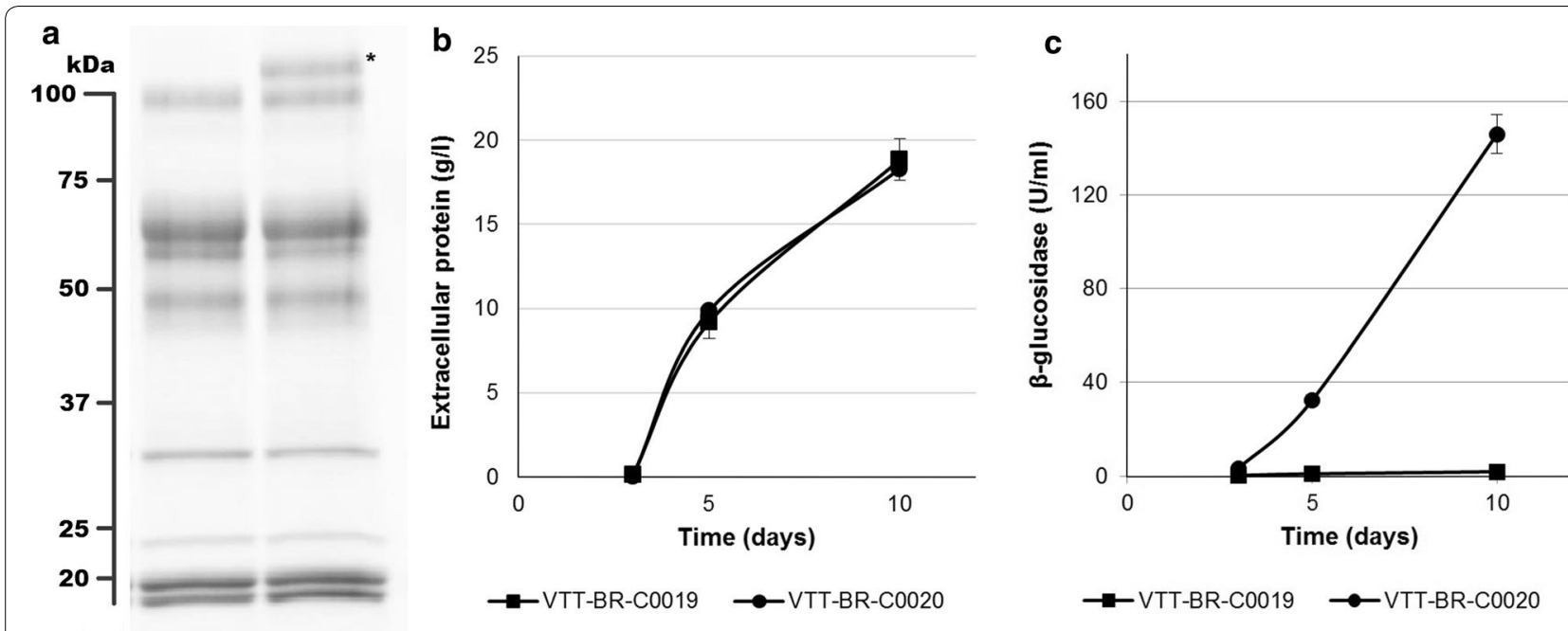

Fig. 5 Production of enzymes by VTT-BR-C0020 in shake flasks on an inducing medium as compared to the parental strain VTT-BR-C0019. T. reesei strains VTT-BR-C0020 and VTT-BR-C0019 were cultivated in shake flasks on an inducing medium (1\% yeast extract, $4 \%$ milk whey, $4 \%$ Avicel). a Culture supernatant samples from the last cultivation day (day 10) visualized on a SDS-PAGE gel. Left lane Parental strain VTT-BR-C0019, right lane VTT-BR-C0020. Additional band corresponding to the heterologous beta-glucosidase is marked with an asterisk. b Extracellular protein measured from cultivation samples of the parental strain VTT-BR-C0019 and VTT-BR-C0020. c $\beta$-Glucosidase activity measured from cultivation samples of the parental strain VTT-BR-C0019 and VTT-BR-C0020

molasses. As the T. reesei genome encodes no invertase [41], the sucrose in the molasses was inverted using hydrochloric acid prior to its use as a feed. The fermentation was terminated after $120 \mathrm{~h}$ with the final extracellular enzyme titer reaching $30.8 \mathrm{~g} / \mathrm{l}$ (Additional file 2: Figure S1), or about $50 \%$ more than what was achieved on soybean hulls alone. The overall enzyme productivity was also higher at about $0.26 \mathrm{~g} / \mathrm{l} \mathrm{h}$.

To understand the potential of the produced enzyme mixture, we used it to hydrolyze industrial hydrothermally pre-treated sugarcane straw. As the original strain M44 produces no enzymes on molasses (Fig. 1), the performance of the new enzyme was compared to the culture supernatant of the original strain cultivated on soybean hulls alone (Additional file 2: Figure S1). Figure 6 shows the relative specific activities measured from these two enzyme preparations. As expected, the principal differences were to be found in the activities xylanase, $\beta$-xylosidase, and $\beta$-glucosidase. The enzymes produced by VTT-BR-C0020 showed an approximately twofold, fivefold and 400-fold increase in these activities, respectively. Activities reflecting some of the main cellulases (endoglucanase and MUL) remained relatively unaltered.

The hydrolysis results show a dramatic increase in the ability of the improved enzymes to release glucose (Fig. 7a) and xylose (Fig. 7b) from the pre-treated sugarcane straw. Total monomeric sugar concentrations (glucose + xylose) in the hydrolysate surpassed $100 \mathrm{~g} / \mathrm{l}$ with an enzyme dose of $10 \mathrm{mg} / \mathrm{g}$ total substrate solids.
The result is probably the consequence of the increased $\beta$-glucosidase activity and the additional xylanolytic activities, particularly $\beta$-xylosidase.

\section{Creation of strain VTT-BR-C0022 expressing invertase from Aspergillus niger}

The previous results showed that it would be possible to produce a well-performing enzyme using the strain VTTBR-C0020 and only the low-cost raw materials soybean hulls, sugarcane molasses, and $\left(\mathrm{NH}_{4}\right)_{2} \mathrm{SO}_{4}$. However, as T. reesei lacks a native invertase [41], an additional process step was required to hydrolyze the sucrose in molasses with acid. Aside from adding to process complexity, such a step might generate compounds inhibitory to the enzyme-producing fungus. Indeed, our method of acid inversion was found to lead to a significant decrease in tolerance by our $T$. reesei strain toward this carbon source. In shake flask culture, the strain VTT-BR-C0020 only tolerated the acid-inverted molasses up to a total reducing sugar (TRS) concentration of about $50 \mathrm{~g} / \mathrm{l}$, while in-natura molasses was tolerated up to $200 \mathrm{~g} / \mathrm{l}$ TRS, the highest concentration evaluated (data not shown). To reach yet higher enzyme concentrations, more concentrated soluble carbon source would be required. A strain able to consume sucrose was therefore obviously desirable.

Trichoderma reesei has previously been engineered to express the suc1 invertase from Aspergillus niger [41]. We used the same gene, including the native $A$. niger 


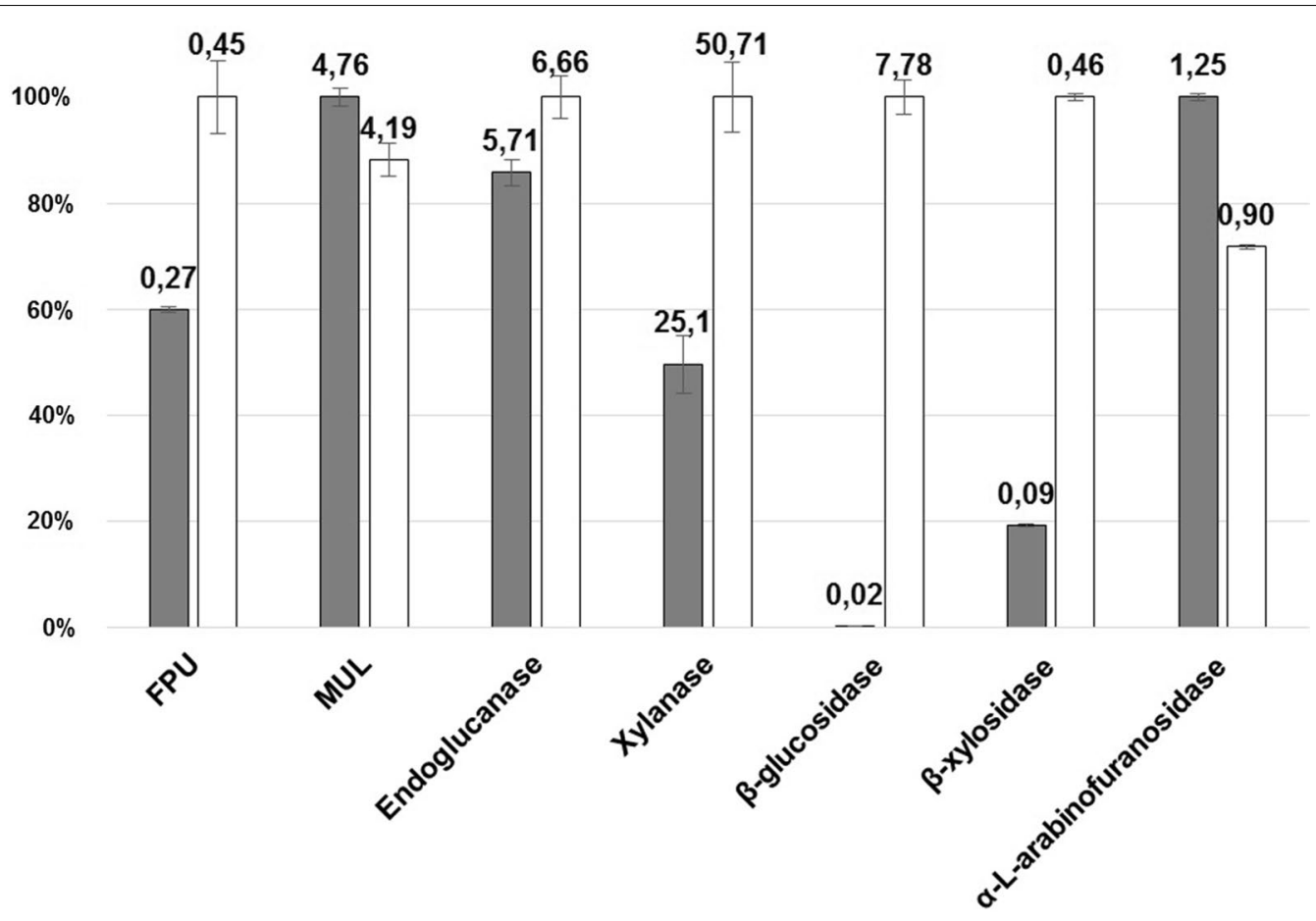

$\square$ M44 (Soybean hulls)

$\square$ VTT-BR-C0020 (Soybean hulls + sugarcane molasses)

Fig. 6 Profile of enzymes produced by original strain M44 on soybean hulls and strain VTT-BR-C0020 on soybean hulls and acid-inverted sugarcane molasses. Comparison of specific enzymatic activities quantified from culture supernatants of the original strain M44 cultivated on soybean hulls and the strain VTT-BR-C0020 cultivated on soybean hulls and acid-inverted sugarcane molasses. The bar heights give relative specific activities between the two enzyme mixtures, while the numeric labels give the specific activities in units/milligram of protein

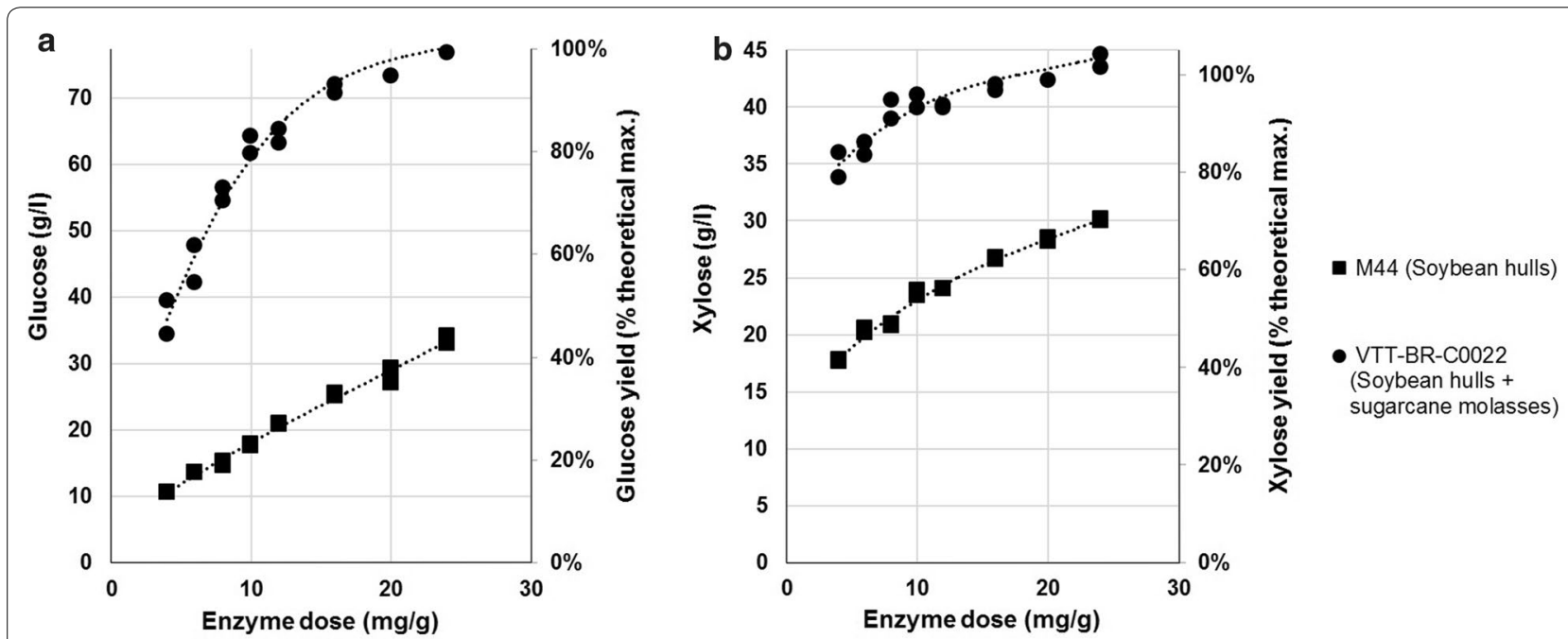

Fig. 7 Relative performance of the enzymes produced by the original strain M44 and the strain VTT-BR-C0020 in the hydrolysis of industrial hydrothermally pre-treated sugarcane straw. The ability of the enzymes produced by M44 on soybean hulls to hydrolyze industrial hydrothermally pretreated sugarcane straw was compared to the enzymes produced by VTT-BR-C0020 on soybean hulls and sugarcane molasses. The used enzyme dose varied from 4 to $24 \mathrm{mg} / \mathrm{g}$ substrate dry matter, and the reactions were carried out for $72 \mathrm{~h}$ at $45^{\circ} \mathrm{C}$ at a total substrate solids loading of $20 \%$. a Glucose liberation as measured by HPLC, b xylose liberation as measured by HPLC. Results displayed as concentration (g/l—primary axes) and as a percentage of the theoretical maximum (\%-secondary axes) 
promoter, to transform VTT-BR-C0020 with the aim of providing low-level invertase expression sufficient for growth on sucrose. Invertase would not contribute to biomass hydrolysis, so high-level expression was undesirable. This gene was transformed together with an overexpression construct for the activator of cellulase expression ace 2 [42], driven by the pdc1 promoter. The gene thi4 [43] conferring resistance to pyrithiamine was used as a selectable marker (see Additional file 3: Table S2 for vector design). Transformants were screened in deep well plates containing mineral medium with sucrose as the only carbon source. The transformant exhibiting the best growth on sucrose mineral medium (VTT-BRC0022) was selected as our final strain.

To study the behavior of the final strain, we performed shake flask cultivations comparing it to the parental strain VTT-BR-C0020 using three different carbon sources: (a) a combination of pure glucose and fructose, (b) pure sucrose, and (c) sugarcane molasses. Figure 8 shows the consumption of sugars and production of extracellular protein by the two strains. On glucose and fructose, strain VTT-BR-C0022 appeared to produce slightly higher concentrations $(8.6 \mathrm{~g} / \mathrm{l})$ of enzymes as compared to the parental strain $(6.9 \mathrm{~g} / \mathrm{l})$. Production of enzymes by VTT-BR-C0022 on pure sucrose reached similar levels $(7.9 \mathrm{~g} / \mathrm{l})$ to those observed on the mixture of glucose and fructose, while as expected, no sucrose was consumed and no enzymes produced by the parental VTT-BR-C0020. Molasses seemed to be a better carbon source than pure sugars, with VTT-BR-C0022 reaching final enzyme titers of $11.8 \mathrm{~g} / \mathrm{l}$ compared to $8-9 \mathrm{~g} / \mathrm{l}$ for pure sugars. The parental strain again consumed no sucrose, but was able to produce up to $5.9 \mathrm{~g} / \mathrm{l}$ of enzyme on the glucose and fructose contained in molasses alone.

To study the sucrose consumption and enzyme production of the final strain VTT-BR-C0022, we also performed fermentations with non-inverted sugarcane molasses (Fig. 9). In one reactor, the inoculum and batchphase growth were carried out on sugarcane molasses only (Fig. 9a), while in the other one, the inoculum and batch medium were supplemented with $50 \mathrm{~g} / \mathrm{l}$ of milled soybean hulls (Fig. 9b). In both cases, the strain VTT-BRC0022 was able to invert all sucrose in the batch medium and in the feed. Only slight accumulation of fructose was observed in the pure molasses cultivation. In these cultivations, we were able to reach extracellular protein concentrations of $34.1 \mathrm{~g} / \mathrm{l}$ in $214 \mathrm{~h}(0.16 \mathrm{~g} / \mathrm{l} \mathrm{h})$ on molasses alone (Fig. 9a), and $37.3 \mathrm{~g} / \mathrm{l}$ in $183 \mathrm{~h}(0.20 \mathrm{~g} / \mathrm{l} \mathrm{h})$ when combined with soybean hulls (Fig. 9b). These results demonstrate that using the described strain and raw materials, industrially relevant enzyme productivities and titers could be achieved.

\section{Use of whole enzyme broth for hydrolysis and SSF}

One advantage of producing cellulases at their final site of use is considered to be the possibility of avoiding clarification of the enzyme. However, only a limited number of studies have been performed using a whole enzyme broth, including fungal mycelia, to hydrolyze lignocellulosic biomass [7, 8]. Additionally, to the best of our knowledge, the possible effects of fungal mycelia on the ethanologen have not been studied in detail. To
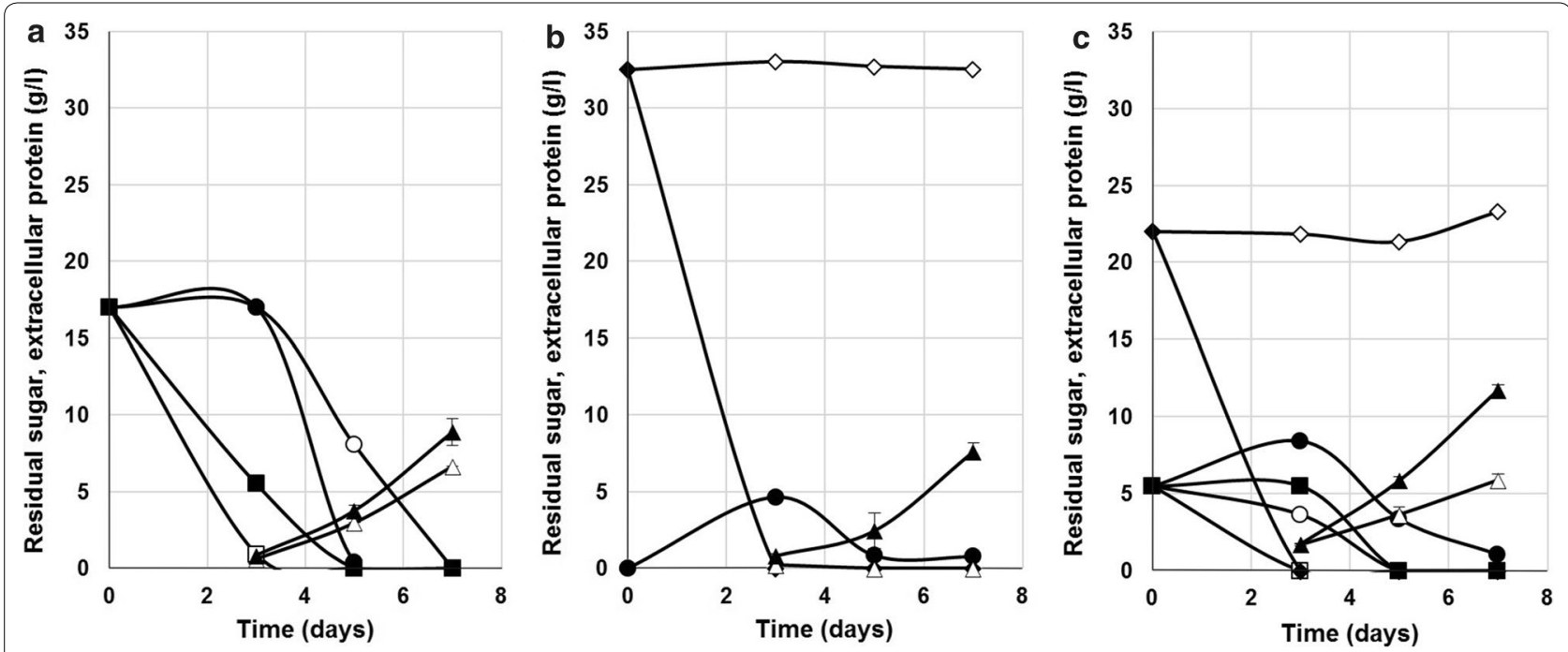

Fig. 8 Utilization of sugars and production of extracellular proteins by VTT-BR-C0022 as compared to parental strain VTT-BR-C0020. Consumption of glucose, fructose and sucrose, and secretion of extracellular protein by invertase-expressing strain VTT-BR-C0022 and parental strain VTT-BR-C0020 cultivated on three different carbon sources: a pure glucose + fructose, $\mathbf{b}$ pure sucrose and $\mathbf{c}$ sugarcane molasses. In all cases the carbon source was used at a concentration of $30 \mathrm{~g} / \mathrm{l}$ and supplemented with $3 \mathrm{~g} / \mathrm{l}$ yeast extract as an organic nitrogen source 

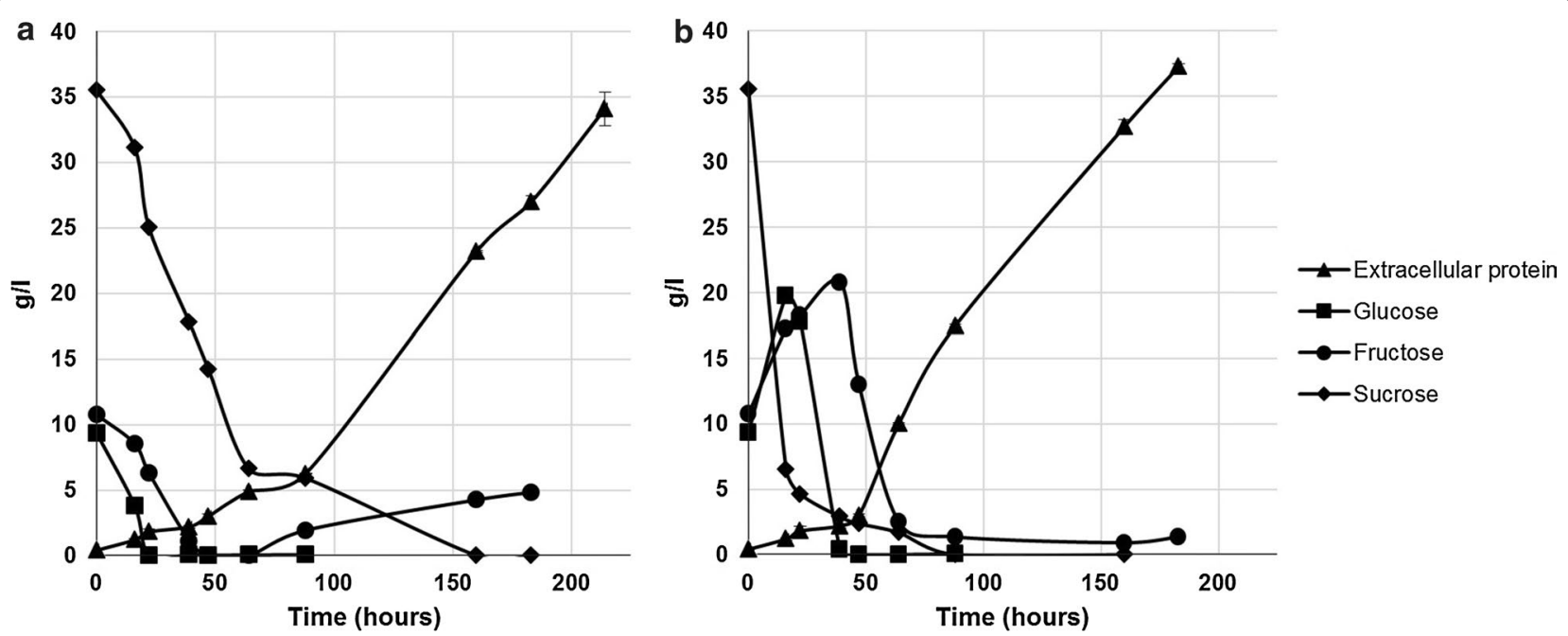

Fig. 9 Sugar consumption and extracellular enzyme production by strain VTT-BR-C0022 in sugarcane molasses -containing media in bioreactor cultivation. Strain VTT-BR-C0022 was cultivated in bioreactors on sugarcane molasses based media. Residual glucose, fructose and sucrose, and extracellular protein measured from cultivation supernatant samples. a Cultivation with only $50 \mathrm{~g} / \mathrm{l}$ total sugars from sugarcane molasses in batch phase and a sugarcane molasses feed. b Cultivation with $50 \mathrm{~g} / \mathrm{l}$ total sugars from sugarcane molasses supplemented with $50 \mathrm{~g} / \mathrm{l}$ milled soybean hulls in batch phase and a sugarcane molasses feed

understand if whole enzyme broth produced using our method could indeed be used for hydrolysis and ethanol fermentation, we performed simultaneous saccharification and fermentation (SSF)-type reactions in shake flasks. We used aseptically taken final samples of the fermentation shown in Fig. 9b to hydrolyze industrially pretreated sugarcane straw (GranBio Ltda.).

For the SSF experiments, it was necessary to wash the pre-treated substrate to allow growth and ethanol production by $S$. cerevisiae. The experiments were carried out with a 48 -h pre-hydrolysis step at $45^{\circ} \mathrm{C}$ prior to fermentation at $33^{\circ} \mathrm{C}$, or as pure SSF reactions at $33{ }^{\circ} \mathrm{C}$. It was known from experience that $45{ }^{\circ} \mathrm{C}$ was sufficient to inactivate $T$. reesei cells (although not spores). Similar final ethanol titers were achieved in both cases, suggesting that the presence of viable fungal cells at the beginning of fermentation did not significantly affect ethanol yield (Fig. 10). Ethanol yields ranging from 60 to $80 \%$ of the theoretical maximum were achieved with the different enzyme doses.

\section{Discussion}

Enzymes remain a major cost factor for the nascent lignocellulosic fuels and chemicals industry. The operational cost of enzymes arises from two main components: the quality of the enzyme (i.e., how much enzyme is needed to hydrolyze a given quantity of biomass) and the cost of each kilogram of enzyme to the end user. The quality of cellulase enzymes and the factors contributing to it are often exhaustively discussed. However, less attention is generally given to the cost of enzyme $(\$ / \mathrm{kg})$ and the factors contributing to this cost, and very little information is available on the production costs of commercial cellulases [1].

In one of the most thorough analyses on the topic to date, with the stated objective of adding transparency to the enzyme cost discussion, Humbird et al. modeled a cellulase production process co-located at a corn ethanol mill [5]. This techno-economic model assumed the use of glucose $(\$ 580 / t)$ as carbon source and found that it accounted for over $50 \%$ of the total cost of the produced enzyme $(\$ 4.24 / \mathrm{kg})$. Other major contributors were the capital invested in equipment (21\%) and the electricity used to run the process (13\%). Even so, the modeled process provided for better economics than the commercially delivered enzymes at the time.

However, this theoretical model assumed a highly performing cellulase production process with an enzyme productivity of $0.42 \mathrm{~g} / \mathrm{l} \mathrm{h}$ and final titer of $50 \mathrm{~g} / \mathrm{l}$ using only glucose as carbon source. In addition, the produced enzyme was assumed to be relatively well performing and dosed at $20 \mathrm{mg} / \mathrm{g}$ of glucan (corresponding roughly to $10 \mathrm{mg} / \mathrm{g}$ dry substrate, the metric used in this study). To the best of our knowledge, these figures are beyond what is reported in the literature, suggesting that sufficiently high-performing strains and processes are not available in the public domain. Previous reports detail hypercellulolytic strains of $T$. reesei producing up to $40 \mathrm{~g} / \mathrm{l}$ of total extracellular protein in $8-10$ days $(\leq 0.2 \mathrm{~g} / \mathrm{l} \mathrm{h})$ on media containing inducers (lactose or cellobiose) [16, 44]. 


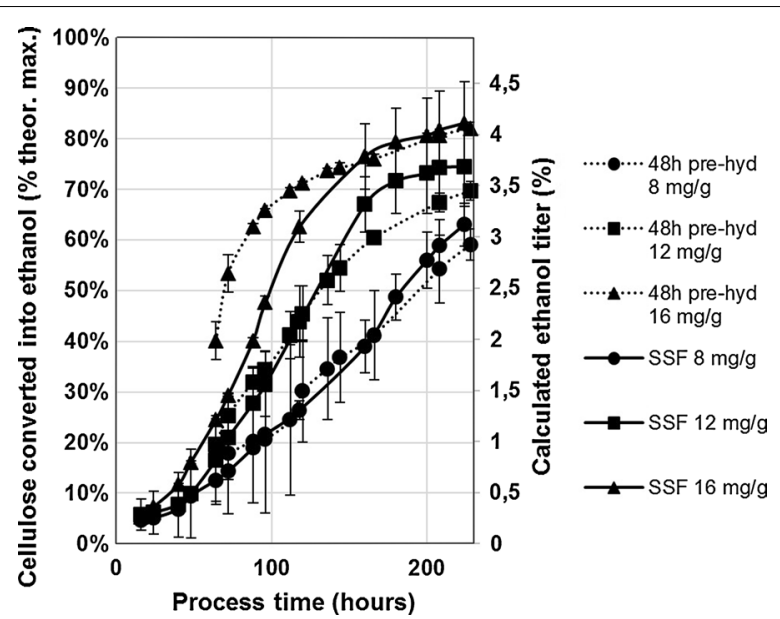

Fig. 10 Hydrolysis and fermentation of washed industrial sugarcane straw using whole enzyme broth including fungal mycelia and other solids. Whole enzyme broth containing fungal mycelia and other solid residues was recovered from the final sample of the bioreactor cultivation of strain VTT-BR-C0022 on soybean hulls and sugarcane molasses (Fig. 9b). The whole enzyme broth was dosed in hydrolysis at 8,12 , and $16 \mathrm{mg} / \mathrm{g}$. The reactions were carried out in two modes: with a 48 -h pre-hydrolysis step at $45^{\circ} \mathrm{C}$ followed by yeast addition and fermentation at $33^{\circ} \mathrm{C}$ and pure simultaneous saccharification and fermentation carried out at $33^{\circ} \mathrm{C}$. The $X$-axis considers the time of both the hydrolysis and fermentation steps. The bottles were weighed periodically, and the loss of weight due to evolution of $\mathrm{CO}_{2}$ was converted into values of cellulose to ethanol conversion (primary $Y$-axis) and ethanol titer (secondary $Y$-axis)

As a means of decreasing enzyme cost, many studies cite the use of lignocellulosic biomass as a carbon source for enzyme production [1, 4, 6, 9-12], and the concept does seem to offer many benefits. By definition, the lignocellulosic biomass used for ethanol production should be of low cost, and the use of the same biomass could allow the enzyme-producing fungus to produce a more specific enzyme mixture for the hydrolysis of the biomass. We initially also considered this alternative. However, the limitations of using lignocellulosic biomass for high-yield enzyme production rapidly became apparent. The principal drawbacks are related to viscosity, nutrient availability, and toxicity.

Fibrous biomass residues have a tendency to absorb great quantities of water, even when milled, and thus lead to highly viscous media. Through our experience, we expect that in-natura sugarcane biomass residues could at most be used at concentrations of around $50 \mathrm{~g} / \mathrm{l}$ in large bioreactors, setting a very low upper limit for achievable enzyme titers. In addition, in-natura biomass is recalcitrant and contains a relatively high proportion of lignin, which soft-rot fungi do not readily consume. Lignin can also non-productively and irreversibly bind cellulases [36], thus potentially decreasing yield.
We assume that all these factors played a role in the low extracellular enzyme titers achieved with our strain on in-natura sugarcane straw (Fig. 1).

Pre-treated biomass is less recalcitrant, but contains an even higher proportion of lignin, aside from toxic inhibitors such as furfural, hydroxymethylfurfural (HMF), and phenolic compounds. In our experience, hydrothermally pre-treated biomass is toxic to $T$. reesei even at very low concentrations $(<30 \mathrm{~g} / \mathrm{l})$. Low cellulase yields and productivities mean prohibitive economics from capital expenditure, even if the raw material cost was next to zero.

Another techno-economic model illustrates some of these points [1]. This model considered inexpensive steam-exploded poplar $(\$ 60 / \mathrm{t})$ as carbon source at high consistency $(\sim 30 \%$ solids $)$ in $T$. reesei -fermentation for enzyme production. Although such a process in our experience seems impossible in practice due to the questions of toxicity and viscosity, the model nonetheless arrived at an enzyme price of over $\$ 10 / \mathrm{kg}$. Notably, costs associated with the financing and operation of equipment accounted for $65 \%$ of the total cost. The financing for and operation of equipment required for submerged, aseptic, aerobic fermentation are costly, and therefore the productivity of the equipment is paramount for the overall economics of the process.

Due to these considerations, we excluded lignocellulosic biomass as an alternative and expanded our scope to identify alternative low-cost Brazilian residues that would serve better for the purpose. Of the options considered, soybean hulls presented by far the most attractive characteristics. Soybean hulls have been used for cellulase production using $T$. reesei in at least two prior studies $[45,46]$, while the more expensive soy derivative soy bran has been used in other publications [47, 48]. We were able to reach productivities of $0.2 \mathrm{~g} / \mathrm{l} \mathrm{h}$ and titers of $20 \mathrm{~g} / \mathrm{l}$ using this residue alone (Fig. 1; Additional file 2: Figure S1). After modification of our production strain, we included sugarcane molasses, a relatively inexpensive, high-density sugar stream as an additional carbon source, increasing the productivity $(0.26 \mathrm{~g} / \mathrm{l} \mathrm{h})$ and titer $(30 \mathrm{~g} / \mathrm{l})$. These figures reach more than $50 \%$ of those assumed in the techno-economic model of Humbird et al. [5], and the productivity is similar to that assumed by Klein-Marcuschamer et al. [1].

We estimated that the nutrients in the medium containing soybean hulls $(\$ 100 / t)$, sugarcane molasses (\$205/t total reducing sugar-TRS), and ammonium sulfate $(\$ 331 / \mathrm{t})$ used to produce enzymes with VTTBR-C0020 (Additional file 2: Figure S1) to have cost around $25 \$ / \mathrm{m}^{3}$ (using the average exchange rate for 2015 of $\$ 1=\mathrm{R} \$ 3.467)$. Considering a final enzyme titer of $30 \mathrm{~kg} / \mathrm{m}^{3}$, this would signify a growth medium cost 
contribution of less than $\$ 1 / \mathrm{kg}$ of the produced enzyme. Factoring in other operational costs and capital cost, the final price of the enzyme produced with these raw materials could by estimate be as low as $\$ 2-4 / \mathrm{kg}$. Our process therefore provides an intermediate between the previously discussed high carbon source price/low capital cost model [5], and the low carbon source cost/high capital cost model [1]. Of note is that both models also included additional nutrient sources, such as corn steep liquor and salts, adding to nutrient cost. Table 1 presents a comparison between some of the key metrics of the discussed techno-economic models and the experimental data presented here.

However, in-depth techno-economic modelling would be required to assess the true cost of the enzyme produced using the process described in this study. One particular consideration is the effect on the process costs of using high solids in enzyme production. On the other hand, we were able to show that high enzyme titers are also achievable without the addition of soybean hull solids using the invertase-expressing strain VTT-BR-C0022 (Fig. 9b).

Besides enzyme cost, we also improved the quality of the enzymes secreted by our production strain by overexpressing the native xylanases of $T$. reesei (through the overexpression of a mutated $x y r 1$ ) and adding a heterologous $\beta$-glucosidase from T. emersonii. These improvements allowed the enzyme to be used in hydrolysis at enzyme loadings similar to those assumed by Humbird et al. [5] and Klein-Marcuschamer [1] (20 mg/g glucan). Using the roughly corresponding dose of $10 \mathrm{mg} / \mathrm{g}$ dry matter, our enzyme hydrolyzed over $80 \%$ of the substrate cellulose and over $90 \%$ of the substrate xylan in $72 \mathrm{~h}$, which should be sufficient for an industrial cellulosic ethanol process. Strikingly, similar glucose yields were achieved with a more than $80 \%$ reduction in enzyme loading compared to the enzyme produced by the original strain (Fig. 7), emphasizing the importance of the modifications made.

In the present study, we also showed that whole fungal fermentation broth containing $T$. reesei mycelia and other solid residues could be used for biomass hydrolysis without any prior processing (Fig. 10), which could potentially bring large savings. The overall cost contribution of enzymes to a cellulosic ethanol process needs to be evaluated on a case-by-case basis.

We also note that this study relied only on a small number of genetic modifications and we assume that significant improvements could be achieved with further strain development. Additional transcription factor modifications could significantly improve enzyme yields and production kinetics. For example, the downregulation of ace1 has been shown to increase enzyme yields in T. reesei Rut-C30 [23], and novel cellulase activators have recently been described [49]. Optimization of the fermentative process might also result in productivity gains. In addition, expressing other enzymes could have a further beneficial impact on enzyme performance. In particular, the addition of lytic polysaccharide monooxygenases (LMPOs) could be expected to improve the hydrolysis performance of the enzymes secreted by the strain [50].

\section{Conclusions}

The aim of the present study was to develop a simple and cost-effective process for the production of cellulases that could be implanted in the context of a Brazilian sugarcane mill. We developed a low-cost growth medium based on soybean hulls and sugarcane molasses and engineered our $T$. reesei production strain for higher productivity and better enzyme profile using a number of previously described modifications. With further

Table 1 Comparison of some of the key metrics of the enzyme production processes described in the techno-economic models of Humbird et al. [5] and Klein-Marcuschamer et al. [1], and the data from this study

\begin{tabular}{llll}
\hline & Humbird [5] & Klein-Marcuschamer [1] & This study $^{\mathbf{a}}$ \\
\hline Carbon source & Glucose & Steam-exploded poplar & $83 \%$ Soybean hulls, 17\% sugarcane molasses \\
C-source price $(\$ / \mathrm{t})$ & 580 & $60^{\mathrm{b}}$ & 120 \\
Enzyme yield from C-source (g/g) & 0.24 & $0.13^{\mathrm{c}}$ & 0.21 \\
Final titer $(\mathrm{g} / \mathrm{l})$ & 50 & 46 & 30.6 \\
Production time $(\mathrm{h})$ & 120 & 192 & 120 \\
Productivity $(\mathrm{g} / \mathrm{l} \mathrm{h})$ & 0.42 & 0.24 & 0.26 \\
Nutrient cost $(\$ / \mathrm{kg}$ enzyme) & 2.63 & 2.84 & $\sim 0.85$ \\
Total enzyme cost $(\$ / \mathrm{kg})$ & 4.24 & 10.14 & $\mathrm{~N} / \mathrm{D}$ \\
\hline
\end{tabular}

a Considering the fermentation performed with VTT-BR-C0020 on a medium with a final concentration of $125 \mathrm{~g} / \mathrm{l}$ soybean hulls and $25 \mathrm{~g} / \mathrm{l}$ molasses TRS (Additional file 1: Figure S1)

b Cost assumed in the base scenario for native poplar, not including the cost of pre-treatment

c Yield from pre-treated poplar total solids 
improvements, such a system could allow the local production of low-cost cellulase in biomass rich regions where limiting infrastructure or other factors favor a distributed enzyme production model.

\section{Methods}

\section{Strains and propagation}

The strain T. reesei M44 and its derivatives were routinely cultivated on petri dishes containing Potato Dextrose Agar (Difco). After 6-10 days, spores were collected in spore solution $(20 \%$ glycerol, $0.8 \% \mathrm{NaCl}, 0.025 \%$ Tween $20)$, filtered through sterile cotton, quantified using a hemocytometer and frozen at $-80{ }^{\circ} \mathrm{C}$ for long-term storage.

\section{Shake flask and microplate cultivations}

The $T$. reesei strains were routinely cultivated in $500 \mathrm{ml}$ baffled Erlenmeyer flasks by inoculating $2^{*} 10^{7}$ spores in

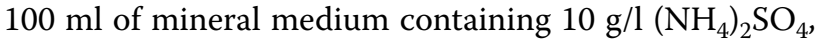
$15 \mathrm{~g} / \mathrm{l} \mathrm{KH_{2 }} \mathrm{PO}_{4}, 0.59 \mathrm{~g} / \mathrm{l} \mathrm{MgSO}_{4}, 0.45 \mathrm{~g} / \mathrm{l} \mathrm{CaCl}, 5 \mathrm{mg} / \mathrm{l}$ $\mathrm{FeSO}_{4} \cdot 7 \mathrm{H}_{2} \mathrm{O}, 2 \mathrm{mg} / \mathrm{l} \mathrm{CoCl}_{2} \cdot 6 \mathrm{H}_{2} \mathrm{O}, 1.6 \mathrm{mg} / \mathrm{l} \mathrm{MnSO} \cdot 4 \mathrm{H}_{2} \mathrm{O}$, $1.4 \mathrm{mg} / \mathrm{ZnSO}_{4} \cdot 7 \mathrm{H}_{2} 0$ and $100 \mathrm{mM}$ buffer (PIPPS-Calbiochem) with the initial $\mathrm{pH}$ adjusted to 4.8 with $\mathrm{KOH}$. Solid carbon sources were autoclaved together with the media within the flasks. When milled solid substrates were used, these were prepared using a Wiley knife mill and milled to pass a $0.59 \mathrm{~mm}$ screen unless otherwise indicated. Sugarcane molasses were autoclaved separately, while pure soluble carbon sources were filter sterilized using a $0.22-\mu$ filter, before addition to the sterilized base media. To invert the sucrose in molasses, a sample was first diluted with water to a total sugar concentration of around $500 \mathrm{~g} / \mathrm{l}$, the $\mathrm{pH}$ was lowered to 2.0 with hydrochloric acid, and the sample then autoclaved using a standard liquid cycle. This procedure was found to invert more than $95 \%$ of the sucrose contained in molasses. $\mathrm{pH}$ was then corrected to 4.0 with $10 \mathrm{M} \mathrm{KOH}$. Cultivations were carried out in a shaking incubator (Infors HT Multitron) with $200 \mathrm{rpm}$ at $28{ }^{\circ} \mathrm{C}$. Samples were withdrawn aseptically on cultivation days $3,5,7$, and 10 , centrifuged at $14,000 \mathrm{~g}$, and the supernatants were stored at $-20^{\circ} \mathrm{C}$ for analysis. In some cases, screening of transformant clones was performed in 24 deep well microplates sealed with Breath-Easy membranes (Sigma), with each well containing $6 \mathrm{ml}$ of media of the same basic composition. Used carbon sources and deviations from the basic media composition are detailed in "Results" section.

\section{Evaluation of low-cost residues}

Several industrial residues were evaluated for their potential as carbon sources for cellulase production. Samples of were sourced from local Brazilian producers, in some cases milled and then evaluated in shake flask cultures using the previously described mineral medium supplemented with the given residues at concentrations varying from 30 to $120 \mathrm{~g} / \mathrm{l}$. Materials were considered toxic to $T$. reesei if no germination of spores was observed by 5 days of shake flask cultivation at the lowest evaluated residue concentration (30 g/l). Rheology was evaluated visually by observing the amount of free liquid in the medium and the ease of agitation at different residue concentrations. Availability and price estimates were gathered from several official Brazilian sources, including Companhia Nacional de Abastecimento (CONAB), Ministério de Agricultura, Pecuária e Abastecimento (MAPA), Instituto Brasileiro de Geografia e Estatística (IBGE) and Indústria Brasileira de Ârvores (IBÁ). The opportunity cost for a sugarcane mill of utilizing molasses for enzyme production (R $\$ 712 / \mathrm{t}$ TRS) was a personal industry communication. The availability of a residue for cellulase production was considered with regard to both total annual production, as well as seasonal and regional variability. The ability to induce enzyme production was evaluated based on the highest extracellular protein titer observed in shake flask cultures.

\section{Fermentations}

Fermentations were performed using the BioFlo/CelliGen 115 system (Eppendorf) and water-jacketed 3.0-1 vessels. As milled soybean hulls and sugarcane molasses were found to provide most nutrients required by $T$. ree$s e i$, the standard fermentation medium comprised only $2 \%\left(\mathrm{NH}_{4}\right)_{2} \mathrm{SO}_{4}$ and $1 \mathrm{ml} / \mathrm{l}$ of $\mathrm{J} 647$ antifoam (Struktol) in addition to the described carbon sources. Aeration was maintained at $0.7 \mathrm{VVM}$ compressed air, $\mathrm{pH}$ between 4.0 and 5.0 using $2 \mathrm{M}$ phosphoric acid and 15\% ammonia, and DO above $20 \%$ with an agitation cascade (400$1000 \mathrm{rpm}$ ). The used initial volume was 1-1.2 L, and the reactors were inoculated with 1:10 volume of 3-7 day old shake flask preculture of the same media composition as the fermentation batch medium. Samples were withdrawn at regular intervals, centrifuged at $21,000 \mathrm{~g}$ for $5 \mathrm{~min}$ and the supernatants stored at $-20^{\circ} \mathrm{C}$ for analysis. Final fermentation samples were withdrawn for hydrolysis experiments. Whole broth samples were used directly, while separate samples were clarified by first centrifuging at $9000 \mathrm{~g}$, filtering through glass fiber filters (Whatman GF/B) and finally through 0.45 PVDF membranes before storage at $-20{ }^{\circ} \mathrm{C}$. When molasses was used as feed, the feeding was terminated $12-24 \mathrm{~h}$ prior to terminating the cultivation. Fermentations were terminated once $\mathrm{pH}$ rose markedly above the set point (4.0), and DO showed a continuous upward trend for more than $6 \mathrm{~h}$, which was interpreted as an indication of starvation. 
In the fermentation with VTT-BR-C0020 (Additional file 2: Figure S1), the inoculum and batch medium contained $130 \mathrm{~g} / \mathrm{l}$ milled soybean hulls, and acid-inverted molasses with a concentration of total sugars of $340 \mathrm{~g} / \mathrm{l}$ were fed from 24 to $96 \mathrm{~h}$ of fermentation at an average rate of $0.38 \mathrm{~g} / \mathrm{l} \mathrm{h}$ total sugars.

In the fermentations using strain VTT-BR-C0022 with only molasses (Fig. 9a), the feed was maintained from 65 to $195 \mathrm{~h}$ of cultivation at a rate of $1 \mathrm{~g} / \mathrm{l} \mathrm{h}$ total sugar. In the cultivation supplemented with soybean hulls (Fig. 9b), the feed was maintained from 72 to $168 \mathrm{~h}$ of cultivation at a rate of $0.5 \mathrm{~g} / \mathrm{l} \mathrm{h}$ total sugar.

\section{Molecular cloning}

All restriction enzymes used in this study were FastDigest enzymes from Thermo Scientific, except for BsaI-HF (NEB). The DNA polymerase (Phusion), ligase (T4 ligase), and DNA ladders were also from Thermo Scientific. The used cloning host (Escherichia coli DH5a) as well as the kits used for purifying DNA from $E$. coli, fungi, and agarose gels were from Zymo Research. Sequencing of plasmids was performed by Helixxa Ltda. using an Applied Biosystems 3500 capillary electrophoresis system.

The plasmids used for the transformation of T. reesei were constructed using the type-II restriction endonuclease $B s a$ I. The plasmids were assembled from 5-6 individual linear fragments with compatible 4-bp 3'-overhangs resulting from digestion with BsaI (Additional file 3). Unlike in the GoldenGate method [51], we performed the digestion and subsequent ligation reactions separately. Each fragment comprised one functional unit of the construct, either the promoter or gene of interest or terminator or marker or the vector backbone (derived from pUC57-Kan), and in selected cases, we added an additional sixth fragment. The individual linear fragments used in ligation were derived directly from PCR-amplification or released from specific pUC57-based storage plasmids. The PCR products or plasmids were digested using BsaI-HF (NEB), the desired DNA-fragment purified from an agarose gel, the DNA was eluted in deionized water and quantified using Infinite 200 NanoQuant (Tecan), and the sample was stored at $-20{ }^{\circ} \mathrm{C}$ until use in ligation. The ligation reactions were carried out for a minimum of $3 \mathrm{~h}$ at room temperature according to the enzyme manufacturer's protocol and $5 \mu \mathrm{l}$ of the final product used to transform chemically competent Zymo 5a cells (Zymo Research).

The plasmid pVTTBR43 was constructed by ligating the fragments $p d c$ promoter, $x y r 1_{-} V 821 F$, pdc terminator and hph-amdS cassette into the pUC57-Kan derived backbone.

The plasmid pVTTBR54 was constructed by ligating the fragments $x y n 1$ promoter, $\mathrm{TeCel} 3 A, x y n 1$ terminator, bar cassette, CBHI 3'-flank into the pUC57-Kan derived backbone.

The plasmid pVTTBR80 was constructed by ligating the fragments $p d c$ promoter, ace $2, p d c$ terminator, thi4, CBHI 3'-prime flank into the pUC57-Kan derived backbone. InFusion cloning (Clontech) was then used to replace the CBHI $3^{\prime}$-flank fragment with the suc1 (sucA) gene of Aspergillus niger to create the plasmid pVTTBR92.

More details on vector construction and the origin of each linear fragment are provided in Additional file 3 and used primers are listed in Additional file 4.

\section{Creation of T. reesei strains VTT-BR-C0019, -C0020, and $-\mathrm{C} 0022$}

Transformation of $T$. reesei was performed essentially as described in [52]. In each case, $5-10 \mu$ g of plasmid was digested with suitable FastDigest (Thermo Scientific) enzymes and the product run on a $0.8 \%$ agarose gel. The desired linear fragment (the transformation cassette) was extracted from the gel and 2-5 $\mu$ g of DNA used to transform $T$. reesei protoplasts, which were then plated in selective top agar. The selection plates comprised $10 \mathrm{~g} / \mathrm{l}\left(\mathrm{NH}_{4}\right)_{2} \mathrm{SO}_{4}, 15 \mathrm{~g} / \mathrm{KH}_{2} \mathrm{PO}_{4}, 0.59 \mathrm{~g} / \mathrm{MgSO} \mathrm{M}_{4}$, $0.45 \mathrm{~g} / \mathrm{l} \mathrm{CaCl} 2,5 \mathrm{mg} / \mathrm{l} \mathrm{FeSO}_{4} \cdot 7 \mathrm{H}_{2} \mathrm{O}, 2 \mathrm{mg} / \mathrm{l} \mathrm{CoCl}{ }_{2} \cdot 6 \mathrm{H}_{2} \mathrm{O}$, $1.6 \mathrm{mg} / \mathrm{l} \mathrm{MnSO} \mathrm{M}_{4} \cdot 4 \mathrm{H}_{2} \mathrm{O}, 1.4 \mathrm{mg} / \mathrm{l} \mathrm{ZnSO} \cdot \cdot 7 \mathrm{H}_{2} 0,15 \mathrm{~g} / \mathrm{l}$ agar and $10 \mathrm{~g} / \mathrm{l}$ glucose as carbon source. Colonies emerging from the top-agar were picked between 5 and 10 days after plating and re-streaked on selective plates. After 5-7 days, a spore suspension was prepared from these plates, diluted sufficiently and plated on selective plates containing $0.1 \%$ Triton X-100 as a colony restrictor. Isolated colonies arising from single spores were then picked and streaked on PDA to generate a final suspension of spores that could be used for cultivations in liquid media. Cultivations in liquid media were used to verify desired phenotypes and prepare cell mass for genomic DNA extraction using the ZR Fungal/Bacterial DNA MiniPrep kit (Zymo Research). Integration of the transformation cassette was verified from genomic DNA using PCR and suitable primer combinations.

To create strain VTT-BR-C0019, protoplasts prepared from M44 were transformed with the linear fragment resulting from the digestion of pVTTBR43 with MssI. The protoplasts were plated in top-agar containing $50 \mu \mathrm{g} /$ ml Hygromycin B (Calbiochem). 5 purified transcription factor transformants were screened in shake flask culture for their ability to secrete more extracellular enzymes than the parental strain, and the best transformant (VTT-BR-C0019) was selected for further improvement.

To create strain VTT-BR-C0020, protoplasts prepared from VTT-BR-C0019 were transformed with the linear fragment resulting from the digestion of pVTTBR54 with 
MssI and NheI. The protoplasts were plated in top-agar containing $1 \mathrm{mg} / \mathrm{ml}$ glufosinate-ammonium (Sigma). 9 purified clones were screened in shake flask culture for their ability to secrete more beta-glucosidase (pNPGase) than the parental strain, and the best one (VTT-BRC0020) was selected for further improvement.

To create strain VTT-BR-C0022, protoplasts prepared from VTT-BR-C0020 were transformed with the linear fragment resulting from the digestion of PVTTBR92 with MssI. The protoplasts were plated in top-agarose containing $100 \mu \mathrm{g} / \mathrm{ml}$ pyrithiamine (Sigma) and sucrose instead of glucose as the carbon source. 10 purified clones were screened in microplate culture for their ability to produce invertase and grow on mineral medium with sucrose as the only carbon source, and the best one (VTT-BRC0022) was selected as the final strain.

\section{Enzyme sample analysis}

Cultivation supernatant samples from shake flasks and bioreactors were routinely analyzed for total protein content and enzymatic activities.

For quantifying protein, the sample was first diluted to a final concentration of $0.3-1.5 \mathrm{~g} / \mathrm{l}$ in $50 \mathrm{mM} \mathrm{pH} 5.0$ Na-citrate buffer. A $200 \mu \mathrm{l}$ sample was combined with $800 \mu \mathrm{l}$ ice-cold acetone in a $2 \mathrm{ml}$ Eppendorf tube, mixed by inverting the tube several times and then maintained at $-20{ }^{\circ} \mathrm{C}$ for $1 \mathrm{~h}$. The precipitated proteins were pelleted by centrifuging at $14,000 \mathrm{~g}$ and $4{ }^{\circ} \mathrm{C}$ for $5 \mathrm{~min}$. The supernatant was removed and the pellet was air-dried for $5 \mathrm{~min}$ before resuspending in the original volume (200 $\mu \mathrm{l})$ of buffer. The protein concentration was then quantified using the DC protein kit (BioRad) based on the method of Lowry [53] using Bovine Serum Albumin (BSA) as standard. Filter paper activity (FPase) was measured using the standard method [54].

The enzymatic activities $\beta$-glucosidase, $\beta$-xylosidase and $\alpha$-L-arabinofuranosidase were measured using the substrates 4-nitrophenyl- $\beta$-D-glucopyranoside (pNPG), 4-nitrophenyl- $\beta$-D-xylopyranoside (pNPX) and 4-nitrophenyl- $\alpha$ - $\mathrm{L}$-arabinofuranoside (pNPA), respectively. The reactions were carried out in $50 \mathrm{mM}$ citrate buffer at $\mathrm{pH} 5.0$ and at $50{ }^{\circ} \mathrm{C}$ for $10 \mathrm{~min}$, the reactions terminated by adding one volume of $1 \mathrm{M} \mathrm{NaCO}_{3}$ and the released 4-nitrophenol quantified by measuring absorbance at $405 \mathrm{~nm}$.

MUL activity was measured using the substrate methylumberriferyl- $\beta$-D-lactoside [37]. The primary T. reesei enzymes active toward this substrate are the GH7-family proteins cellobiohydrolase I (CBHI, Cel7A) and endoglucanase I (EGI, Cel7B), while other enzymes might also display limited activity. The reactions were carried out in $50 \mathrm{mM}$ citrate buffer at $\mathrm{pH} 5.0$ and $50{ }^{\circ} \mathrm{C}$ for $10 \mathrm{~min}$, the reactions were terminated by adding one volume of $1 \mathrm{M} \mathrm{NaCO}_{3}$ and the released methylumberriferone quantified by measuring fluorescence at $445 \mathrm{~nm}$ using an excitation wavelength of $380 \mathrm{~nm}$.

Endoglucanase and xylanase activities were measured using the substrates carboxymethylcellulose $(\mathrm{CMC})$ and beechwood xylan, respectively. The reactions were carried out in $50 \mathrm{mM}$ citrate buffer at $\mathrm{pH} 5.0$ and at $50{ }^{\circ} \mathrm{C}$ for 5 or $10 \mathrm{~min}$, the reactions were terminated by adding 1.5 volumes of DNS reagent. The reactions were heated for $5 \mathrm{~min}$ at $95^{\circ} \mathrm{C}$, and the released reducing sugars were quantified by measuring absorbance at $540 \mathrm{~nm}$. Standard curves were prepared using pure glucose or xylose as appropriate.

Unless otherwise noted, error bars represent standard deviation from biological and experimental duplicates. In all cases, one unit of enzymatic activity was defined as the amount of enzyme releasing one micromole of product from the substrate in one minute under the reaction conditions specified. All substrates and standards used in the enzyme assays were from Sigma.

For visualization of enzyme samples on polyacrylamide gels, 15-20 $\mu \mathrm{g}$ samples based on the Bio-Rad DC measurement were loaded into individual wells on 4-20\% Criterion TGX Strain-Free precast gels (Bio-Rad), run for 30 min with $200 \mathrm{~V}$ and gel images were captured using the Gel Doc EZ system (Bio-Rad).

\section{Hydrolysis}

Hydrolysis reactions were performed in miniature scale using the Intellimixer agitation device (Elmi) set to program $2 \mathrm{u} 18$ and maintained at a temperature of $45{ }^{\circ} \mathrm{C}$ in an incubator cabinet. The substrate used was hydrothermally pre-treated sugarcane straw from an industrial facility (GranBio, São Miguel dos Campos, AL, BR), a kind gift of CTO Gonçalo Pereira. The substrate $\mathrm{pH}$ was adjusted to 5.0 using $10 \mathrm{M} \mathrm{NaOH}$. Each individual hydrolysis reaction was set up to have a total mass of $1 \mathrm{~g}$ within a $2 \mathrm{ml}$ Eppendorf tube. $200 \mathrm{mg}$ of substrate (drybasis) was added into each tube. The reaction was then completed to $1 \mathrm{~g}$ by adding distilled water, enzyme, $\mathrm{NaN}_{3}$ as an anti-microbial agent to a final concentration of $0.02 \%$ and $\mathrm{pH} 5.0$ citrate buffer to a final concentration of $50 \mathrm{mM}$. After $72 \mathrm{~h}$ the entire contents of each tube was recovered in $9 \mathrm{ml}$ of deionized water in a $15 \mathrm{ml} \mathrm{Fal-}$ con tube, mixed thoroughly and centrifuged for $10 \mathrm{~min}$ at $2880 \mathrm{~g}$. A sample $(1 \mathrm{ml})$ of the supernatant was transferred to a $1.5 \mathrm{ml}$ Eppendorf tube, boiled for $10 \mathrm{~min}$ and then stored for analysis. Total reducing sugar was quantified using the DNS method and glucose as standard, and glucose and xylose were quantified using HPLC. To translate the results into degree of hydrolysis, samples of 
the pre-treated material were hydrolyzed with sulfuric acid according to the NREL protocol TP-510-42618 to quantify the maximal potential glucose and xylose.

\section{Shake flask hydrolysis and fermentation experiments}

Evaluation of whole enzyme broth including fungal mycelia in the hydrolysis and fermentation of biomass was performed in $250 \mathrm{ml}$ Erlenmeyer flasks essentially as described in the NREL protocol TP-510-42630. The used enzyme was an aseptically drawn final sample from a fermentation of the strain VTT-BR-C0022 on soybean hulls and sugarcane molasses (Fig. 9b). A sample of this whole broth was diluted 30 -fold in $50 \mathrm{mM}$ citrate $\mathrm{pH}$ 5.0, mixed and centrifuged. The protein quantified from the resulting supernatant $(33.2 \mathrm{~g} / \mathrm{l})$ was considered for enzyme loading. The industrial pre-treated sugarcane straw substrate was washed twice with 5 volumes of $\sim 80^{\circ} \mathrm{C}$ deionized water to remove fermentation inhibitors, and the $\mathrm{pH}$ was adjusted to $\sim 5.5$ with $\mathrm{NaOH}$. The biomass was then sterilized in an autoclave $\left(120{ }^{\circ} \mathrm{C}, 20 \mathrm{~min}\right)$, and the dry-weight was quantified as previously. The $\mathrm{pH}$ of the biomass after autoclaving was $\sim 5.1 .10 \mathrm{~g}$ of substrate (dry basis) were loaded into each flask, along with $5 \mathrm{ml}$ of $500 \mathrm{mM}$ citrate buffer at $\mathrm{pH}$ 5.1. The reaction was then filled up to $47.5 \mathrm{~g}$ with enzyme and water. An inoculum of $S$. cerevisae was prepared by cultivating overnight in $2 \%$ yeast extract, $1 \%$ peptone, and $5 \%$ dextrose (YPD5) medium. The cells were harvested by centrifugation $\left(10 \mathrm{~min}, 1620 \mathrm{~g}, 4{ }^{\circ} \mathrm{C}\right)$ and resuspended in sterile $0.9 \%$ $\mathrm{NaCl}$. The cells were centrifuged again and finally resuspended in $10 \times$ Yeast Nitrogen Base (Sigma) to a final concentration of $20 \mathrm{~g}$ dry cell weight/l, and $2.5 \mathrm{ml}$ of this suspension added to each flask to initiate fermentation with an initial pitch of $1 \mathrm{~g}$ dry cell weight/l. The flasks were purged with a sterile flow of nitrogen for $3 \mathrm{~min}$, while adding the yeast inoculum and capped with bubble locks filled with $5 \mathrm{ml}$ of sterile glycerol. The flasks were weighed after adding the yeast inoculum and at regular intervals thereafter. The weight loss of the bottles (due to $\mathrm{CO}_{2}$ evolution) was converted into ethanol concentration and glucan conversion.

\section{HPLC}

High-performance liquid chromatography was used to quantify glucose, fructose, sucrose and xylose from cultivation and hydrolysis samples. The system used was Waters 1515 pump and 2414 detector at $50{ }^{\circ} \mathrm{C}$, using a Rezex RFQ-Fast Acid $\mathrm{H}+$ column at $85^{\circ} \mathrm{C}$ and a flow rate of $0.8 \mathrm{ml} / \mathrm{min}$ of $5 \mathrm{mM} \mathrm{H}_{2} \mathrm{SO}_{4}$ as the mobile phase. For samples containing sucrose the temperature was lowered to $35^{\circ} \mathrm{C}$ and the flow rate to $0.6 \mathrm{ml} / \mathrm{min}$. Sugar standards were from Sigma Aldrich.

\section{Additional files}

Additional file 1: Table S1. The industrial residues evaluated for cellulase production using T. reesei M44 in shake flask culture.

Additional file 2: Figure S1. Production of extracellular protein in bioreactor cultivations by T. reesei M44 on soybean hulls and VTT-BR-C0020 on soybean hulls and a feed comprising acid-invertsed sugarcane molasses.

Additional file 3: Table S2. The design of the vectors used to create strains VTT-BR-C0019, -C0020 and-C0022.

Additional file 4: Table S3. Primers used in the assembly of vectors pVTTBR43, pVTTBR54 and PVTTBR92, and for verification of inserts from genomic DNA.

\section{Abbreviations}

MESP: minimum ethanol selling price; MUL: 4-methylumbelliferyl- $\beta-D-$ lactopyranoside; CBH: cellobiohydrolase; EG: endoglucanase; SSF: simultaneous saccharification and fermentation; TRS: total reducing sugar; WVM: volume per volume per minute; PVDF: poyvinylidene fluoride; DO: dissolved oxygen; pNPG: 4-nitrophenyl- $\beta$-D-glucopyranoside; PNPX: 4-nitrophenyl- $\beta$-Dxylopyranoside; pNPA: 4-nitrophenyl-a-L-arabinofuranoside; CMC: carboxymethylcellulose; DNS: dinitrosalicylic acid.

\section{Authors' contributions}

SE wrote the manuscript, devised the cloning strategies, built the majority of vectors and participated in the design and execution of cultivations, enzyme assays and hydrolysis experiments. LF helped design and executed most cultivations, enzyme assays and hydrolysis experiments, and significantly participated in interpreting the results. CU built vectors, transformed T. reesei, screened transformants and participated in most experimental work. JC helped devise the overall experimental approach and participated in initial experimental work. MS guided setting up the T. reesei molecular biology methods and participated in interpretation of results. GG participated in the design and construction of vectors. VS administered the work. MSA was instrumental in devising the project, helped interpret the results and direct the work. All authors commented on the manuscript. All authors read and approved the final manuscript.

\section{Author details}

${ }^{1}$ VTT Brasil Ltda., Barueri, Sao Paulo, Brazil. ${ }^{2}$ Present Address: VTT Technical Research Centre of Finland, Tietotie 2, 02044 Espoo, Finland. ${ }^{3}$ Present Address: Instituto de Ciências Agrárias, Universidade Federal de Minas Gerais (UFMG), Montes Claros, MG, Brazil. ${ }^{4}$ Faculdade de Ciências Farmacêuticas de Ribeirão Preto, Universidade de Sao Paulo, Ribeirão Preto, SP, Brazil.

\section{Acknowledgements}

The authors wish to thank Luciano da Silva for performing HPLC analyses and Marcos Barbosa for acid hydrolysis of biomass samples. Jussi Joensuu is thanked for providing several of the original vectors used for cloning. Marcela Savoldi is thanked for assembling initial vectors for $\beta$-glucosidase expression. CSO Gonçalo Pereira from GranBio Ltda. is graciously acknowledged for providing samples of in-natura and industrial hydrothermally pre-treated sugarcane straw.

\section{Competing interests}

SE, LF and CU have deposited a patent application for alternative applications of T. reesei strain VTT-BR-C0020 (PCT/BR2016/000039).

\section{Availability of data and materials}

The datasets used and/or analyzed during the current study available from the corresponding author on reasonable request.

\section{Funding}

This work was financed by the FINEP grant 03.13.0105.00 "Produção de etanol da biomassa de cana-de-açúcar, com produção de enzimas on-site e fermentação de açúcares C5". 
Received: 24 November 2016 Accepted: 25 January 2017 Published online: 02 February 2017

\section{References}

1. Klein-Marcuschamer D, Oleskowicz-Popiel P, Simmons BA, Blanch HW. The challenge of enzyme cost in the production of lignocellulosic biofuels. Biotechnol Bioeng. 2012;109:1083-7.

2. McMillan JD, Jennings EW, Mohagheghi A, Zuccarello M. Comparative performance of precommercial cellulases hydrolyzing pretreated corn stover. Biotechnol Biofuels. 2011;4:29.

3. Barta Z, Kovacs K, Reczey K, Zacchi G. Process design and economics of on-site cellulase production on various carbon sources in a softwoodbased ethanol plant. Enzyme Res. 2010;2010:734182.

4. Delabona Pda S, Farinas CS, da Silva MR, Azzoni SF, Pradella JG. Use of a new Trichoderma harzianum strain isolated from the Amazon rainforest with pretreated sugar cane bagasse for on-site cellulase production Bioresour Technol. 2012;107:517-21.

5. Humbird D, Davis R, Tao L, Kinchin C, Hsu D, Aden A, Schoen P, Lukas J, Olthof B, Worley M, Sexton D, Dudgeon D. Process design and economics for biochemical conversion of lignocellulosic biomass to ethanol. Volume NREL/TP-51. NREL; 2011. http://www.nrel.gov/docs/fy11 osti/47764.pdf.

6. Lau MW, Bals BD, Chundawat SPS, Jin M, Gunawan C, Balan V, Jones AD, Dale BE. An integrated paradigm for cellulosic biorefineries: utilization of lignocellulosic biomass as self-sufficient feedstocks for fuel, food precursors and saccharolytic enzyme production. Energy Environ Sci. 2012:5:7100-10.

7. Liming X, Xueliang S. High-yield cellulase production by Trichoderma reesei ZU-02 on corn cob residue. Bioresour Technol. 2004;91:259-62.

8. Kovacs K, Szakacs G, Zacchi G. Comparative enzymatic hydrolysis of pretreated spruce by supernatants, whole fermentation broths and washed mycelia of Trichoderma reesei and Trichoderma atroviride. Bioresour Technol. 2009;100:1350-7.

9. Dashtban M, Buchkowski R, Qin W. Effect of different carbon sources on cellulase production by Hypocrea jecorina (Trichoderma reesei) strains. Int J Biochem Mol Biol. 2011:2:274-86.

10. Rana V, Eckard AD, Teller P, Ahring BK. On-site enzymes produced from Trichoderma reesei RUT-C30 and Aspergillus saccharolyticus for hydrolysis of wet exploded corn stover and loblolly pine. Bioresour Technol. 2014;154:282-9

11. Sipos B, Benko Z, Dienes D, Reczey K, Viikari L, Siika-aho M. Characterisation of specific activities and hydrolytic properties of cell-wall-degrading enzymes produced by Trichoderma reesei Rut C30 on different carbon sources. Appl Biochem Biotechnol. 2010;161:347-64

12. Alvira P, Gyalai-Korpos M, Barta Z, Oliva JM, Réczey K, Ballesteros M. Production and hydrolytic efficiency of enzymes from Trichoderma reesei RUTC30 using steam pretreated wheat straw as carbon source. J Chem Technol Biotechnol. 2013;88:1150-6.

13. Liu G, Zhang J, Bao J. Cost evaluation of cellulase enzyme for industrialscale cellulosic ethanol production based on rigorous Aspen Plus modeling. Bioprocess Biosyst Eng. 2016;39:133-40.

14. Merino ST, Cherry J. Progress and challenges in enzyme development for biomass utilization. Adv Biochem Eng Biotechnol. 2007;108:95-120.

15. Cherry JR, Fidantsef AL. Directed evolution of industrial enzymes: an update. Curr Opin Biotechnol. 2003;14:438-43.

16. Jourdier E, Cohen C, Poughon L, Larroche C, Monot F, Chaabane FB. Cellulase activity mapping of Trichoderma reesei cultivated in sugar mixtures under fed-batch conditions. Biotechnol Biofuels. 2013;6:79.

17. Singhania RR, Patel AK, Sukumaran RK, Larroche C, Pandey A. Role and significance of beta-glucosidases in the hydrolysis of cellulose for bioethanol production. Bioresour Technol. 2013;127:500-7.

18. Pereira LT, Pereira LT, Teixeira RS, Bon EP, Freitas SP. Sugarcane bagasse enzymatic hydrolysis: rheological data as criteria for impeller selection. J Ind Microbiol Biotechnol. 2011;38:901-7

19. Ahamed A, Vermette P. Enhanced enzyme production from mixed cultures of Trichoderma reesei RUT-C30 and Aspergillus niger LMA grown as fed batch in a stirred tank bioreactor. Biochem Eng J. 2008;42:41-6.
20. Portnoy T, Margeot A, Seidl-Seiboth V, Le Crom S, Ben Chaabane F, Linke $R$, Seiboth B, Kubicek CP. Differential regulation of the cellulase transcription factors XYR1, ACE2, and ACE1 in Trichoderma reesei strains producing high and low levels of cellulase. Eukaryot Cell. 2011;10:262-71.

21. Hakkinen M, Valkonen MJ, Westerholm-Parvinen A, Aro N, Arvas M, Vitikainen M, Penttila M, Saloheimo M, Pakula TM. Screening of candidate regulators for cellulase and hemicellulase production in Trichoderma reesei and identification of a factor essential for cellulase production. Biotechnol Biofuels. 2014;7:14.

22. Mach-Aigner AR, Pucher ME, Steiger MG, Bauer GE, Preis SJ, Mach RL. Transcriptional regulation of xyr1, encoding the main regulator of the xylanolytic and cellulolytic enzyme system in Hypocrea jecorina. Appl Environ Microbiol. 2008;74:6554-62.

23. Wang S, Liu G, Wang J, Yu J, Huang B, Xing M. Enhancing cellulase production in Trichoderma reesei RUT C30 through combined manipulation of activating and repressing genes. J Ind Microbiol Biotechnol. 2013;40:633-41.

24. Gudynaite-Savitch L, Hindle CD, White TC: Hosts and fermentation processes for cellulase production. 2010 US patent (20100129880 A1).

25. Derntl C, Gudynaite-Savitch L, Calixte S, White T, Mach RL, Mach-Aigner AR. Mutation of the xylanase regulator 1 causes a glucose blind hydrolase expressing phenotype in industrially used Trichoderma strains. Biotechnol Biofuels. 2013;6:62.

26. Hasper AA, Trindade LM, van der Veen D, van Ooyen AJ, de Graaff LH. Functional analysis of the transcriptional activator XInR from Aspergillus niger. Microbiology. 2004;150(Pt 5):1367-75.

27. Barnett CC, Berka RM, Fowler T. Cloning and amplification of the gene encoding an extracellular beta-glucosidase from Trichoderma reesei: evidence for improved rates of saccharification of cellulosic substrates. Biotechnology. 1991;9:562-7.

28. Zhang J, Zhong Y, Zhao X, Wang T. Development of the cellulolytic fungus Trichoderma reesei strain with enhanced beta-glucosidase and filter paper activity using strong artificial cellobiohydrolase 1 promoter. Bioresour Technol. 2010;101:9815-8.

29. Ma L, Zhang J, Zou G, Wang C, Zhou Z. Improvement of cellulase activity in Trichoderma reesei by heterologous expression of a betaglucosidase gene from Penicillium decumbens. Enzyme Microb Technol. 2011:49:366-71.

30. Murray P, Aro N, Collins C, Grassick A, Penttila M, Saloheimo M, Tuohy M. Expression in Trichoderma reesei and characterisation of a thermostable family 3 beta-glucosidase from the moderately thermophilic fungus Talaromyces emersonii. Protein Expr Purif. 2004;38:248-57.

31. Nakazawa H, Kawai T, Ida N, Shida Y, Kobayashi Y, Okada H, Tani S, Sumitani J, Kawaguchi T, Morikawa Y, Ogasawara W. Construction of a recombinant Trichoderma reesei strain expressing Aspergillus aculeatus beta-glucosidase 1 for efficient biomass conversion. Biotechnol Bioeng. 2012;109:92-9.

32. Dashtban M, Qin W. Overexpression of an exotic thermotolerant betaglucosidase in Trichoderma reesei and its significant increase in cellulolytic activity and saccharification of barley straw. Microb Cell Fact. 2012;11:63.

33. Nakazawa H, Kawai T, Ida N, Shida Y, Shioya K, Kobayashi Y, Okada H, Tani S, Sumitani J, Kawaguchi T, Morikawa Y, Ogasawara W. A high performance Trichoderma reesei strain that reveals the importance of xylanase III in cellulosic biomass conversion. Enzyme Microb Technol. 2016;82:89-95.

34. Adav SS, Chao LT, Sze SK. Quantitative secretomic analysis of Trichoderma reesei strains reveals enzymatic composition for lignocellulosic biomass degradation. Mol Cell Proteomics. 2012;11(M111):012419.

35. Seidl V, Seiboth B. Trichoderma reesei: genetic approaches to improving strain efficiency. Biofuels. 2010;1:343-54.

36. Rahikainen JL, Martin-Sampedro R, Heikkinen H, Rovio S, Marjamaa K, Tamminen T, Rojas OJ, Kruus K. Inhibitory effect of lignin during cellulose bioconversion: the effect of lignin chemistry on non-productive enzyme adsorption. Bioresour Technol. 2013;133:270-8.

37. Bailey MJ, Tahtiharju J. Efficient cellulase production by Trichoderma reesei in continuous cultivation on lactose medium with a computer-controlled feeding strategy. Appl Microbiol Biotechnol. 2003;62:156-62.

38. Bailey MJ, Adamitsch B, Rautio J, von Weymarn N, Saloheimo M. Use of a growth-associated control algorithm for efficient production of a heterologous laccase in Trichoderma reesei in fed-batch and continuous cultivation. Enzyme Microb Technol. 2007;41:484-91. 
39. Juhasz T, Egyhazi A, Reczey K. beta-Glucosidase production by Trichoderma reesei. Appl Biochem Biotechnol. 2005;121-124:243-54.

40. Steiger MG, Vitikainen M, Uskonen P, Brunner K, Adam G, Pakula T, Penttila M, Saloheimo M, Mach RL, Mach-Aigner AR. Transformation system for Hypocrea jecorina (Trichoderma reesei) that favors homologous integration and employs reusable bidirectionally selectable markers. Appl Environ Microbiol. 2011;77:114-21.

41. Berges T, Barreau C, Peberdy JF, Boddy LM. Cloning of an Aspergillus niger invertase gene by expression in Trichoderma reesei. Curr Genet. 1993;24:53-9.

42. Aro N, Saloheimo A, IImen M, Penttila M. ACEIl, a novel transcriptional activator involved in regulation of cellulase and xylanase genes of Trichoderma reesei. J Biol Chem. 2001;276:24309-14.

43. Kubodera T, Yamashita N, Nishimura A. Transformation of Aspergillus sp. and Trichoderma reesei using the pyrithiamine resistance gene (ptrA) of Aspergillus oryzae. Biosci Biotechnol Biochem. 2002;66:404-6.

44. Ike M, Park J, Tabuse M, Tokuyasu K. Controlled preparation of cellulases with xylanolytic enzymes from Trichoderma reesei (Hypocrea jecorina) by continuous-feed cultivation using soluble sugars. Biosci Biotechnol Biochem. 2013;77:161-6.

45. Coffman AM, Li Q, Ju LK. Effect of natural and pretreated soybean hulls on enzyme production by Trichoderma reesei. JAOCS. 2014:91:1331-8.

46. Brijwani K, Oberoi HS, Vadlani PV. Production of a cellulolytic enzyme system in mixed-culture solid-state fermentation of soybean hulls supplemented with wheat bran. Process Biochem. 2010;45:120-8.
47. Kilikian BV, Afonso LC, Souza TFC, Ferreira RG, Pinheiro IR. Filamentous fungi and media for cellulase production in solid state cultures. Braz J Microbiol. 2014;45:279-86.

48. Gasparotto JM, Werle LB, Mainardi MA, Mazutti MA, Federal U, Maria DS. Produção de enzimas celuloliticas de Trichoderma reesei por fermentação em estado sólido e sua aplicação na hidrólise enzimática de biomassa. XX Congresso Brasileiro de Engenharia Química. Florianópolis: Blucher Chemical EngineeringProceedings; 2015: 8.

49. Häkkinen M, Valkonen MJ, Westerholm-parvinen A, Aro N, Arvas M, Vitikainen M. Screening of candidate regulators for cellulase and hemicellulase production in Trichoderma reesei and identification of a factor essential for cellulase production. Biotechnol Biofuels. 2014;7:14.

50. Horn SJ, Vaaje-Kolstad G, Westereng B, Eijsink VG. Novel enzymes for the degradation of cellulose. Biotechnol Biofuels. 2012;5:45.

51. Engler C, Kandzia R, Marillonnet S. A one pot, one step, precision cloning method with high throughput capability. PLoS ONE. 2008;3:e3647.

52. Penttila M, Nevalainen $H$, Ratto M, Salminen E, Knowles J. A versatile transformation system for the cellulolytic filamentous fungus Trichoderma reesei. Gene. 1987;61:155-64.

53. Lowry OH, Rosebrough NJ, Farr AL, Randall RJ. Protein measurement with the Folin phenol reagent. J Biol Chem. 1951;193:265-75.

54. Ghose TK. Measurement of cellulase activities. Pure Appl Chem. 1987;59:257-68.

\section{Submit your next manuscript to BioMed Central and we will help you at every step:}

- We accept pre-submission inquiries

- Our selector tool helps you to find the most relevant journal

- We provide round the clock customer support

- Convenient online submission

- Thorough peer review

- Inclusion in PubMed and all major indexing services

- Maximum visibility for your research

Submit your manuscript at www.biomedcentral.com/submit 